\title{
Investigation of secondary formation of formic acid: urban environment vs. oil and gas producing region
}

\author{
B. Yuan ${ }^{1,2}$, P. R. Veres ${ }^{1,2}$, C. Warneke ${ }^{1,2}$, J. M. Roberts ${ }^{1}$, J. B. Gilman ${ }^{1,2}$, A. Koss ${ }^{1,2}$, P. M. Edwards ${ }^{1,2,{ }^{*} \text {, M. Graus }}{ }^{1,2, * *}$, \\ W. C. Kuster ${ }^{1,2}$, S.-M. Li ${ }^{3}$, R. J. Wild ${ }^{1,2}$, S. S. Brown ${ }^{1}$, W. P. Dubé ${ }^{1,2}$, B. M. Lerner ${ }^{1,2}$, E. J. Williams ${ }^{1}$, J. E. Johnson ${ }^{4,5}$, \\ P. K. Quinn ${ }^{5}$, T. S. Bates ${ }^{4,5}$, B. Lefer ${ }^{6}$, P. L. Hayes ${ }^{2,7, * * *}$, J. L. Jimenez ${ }^{2,7}$, R. J. Weber ${ }^{8}$, R. Zamora ${ }^{1}$, B. Ervens ${ }^{1,2}$, \\ D. B. Millet ${ }^{9}$, B. Rappenglück ${ }^{6}$, and J. A. de Gouw ${ }^{1,2,7}$ \\ ${ }^{1}$ Chemical Sciences Division, Earth System Research Laboratory, National Oceanic and Atmospheric Administration, \\ Boulder, CO, USA \\ ${ }^{2}$ Cooperative Institute for Research in Environmental Sciences, University of Colorado at Boulder, Boulder, CO, USA \\ ${ }^{3}$ Environment Canada, Science and Technology Branch, Toronto, ON, Canada \\ ${ }^{4}$ Joint Institute for the Study of the Atmosphere and Ocean, University of Washington, Seattle, WA, USA \\ ${ }^{5}$ NOAA Pacific Marine Environmental Laboratory (PMEL), Seattle, WA, USA \\ ${ }^{6}$ Department of Earth and Atmospheric Sciences, University of Houston, Houston, TX, USA \\ ${ }^{7}$ Department of Chemistry and Biochemistry, University of Colorado at Boulder, Boulder, CO, USA \\ ${ }^{8}$ School of Earth and Atmospheric Sciences, Georgia Institute of Technology, Atlanta, GA, USA \\ ${ }^{9}$ Department of Soil, Water and Climate, University of Minnesota, St. Paul, Minnesota, USA \\ * now at: Department of Chemistry, University of York, York, UK \\ ** now at: Institute of Meteorology and Geophysics, University of Innsbruck, Innsbruck, Austria \\ *** now at: Université de Montréal, Department of Chemistry, Montreal, QC, Canada
}

Correspondence to: B. Yuan (bin.yuan@noaa.gov)

Received: 29 August 2014 - Published in Atmos. Chem. Phys. Discuss.: 26 September 2014

Revised: 14 January 2015 - Accepted: 30 January 2015 - Published: 24 February 2015

\begin{abstract}
Formic acid ( $\mathrm{HCOOH})$ is one of the most abundant carboxylic acids in the atmosphere. However, current photochemical models cannot fully explain observed concentrations and in particular secondary formation of formic acid across various environments. In this work, formic acid measurements made at an urban receptor site (Pasadena) in JuneJuly 2010 during CalNex (California Research at the Nexus of Air Quality and Climate Change) and a site in an oil and gas producing region (Uintah Basin) in January-February 2013 during UBWOS 2013 (Uintah Basin Winter Ozone Studies) will be discussed. Although the VOC (volatile organic compounds) compositions differed dramatically at the two sites, measured formic acid concentrations were comparable: $2.3 \pm 1.3$ in UBWOS 2013 and $2.0 \pm 1.0 \mathrm{ppb}$ in CalNex. We determine that concentrations of formic acid at both sites were dominated by secondary formation (>99\%). A constrained box model using the Master Chemical Mechanism (MCM v3.2) underestimates the measured formic acid
\end{abstract}

concentrations drastically at both sites (by a factor of $>10$ ). Compared to the original MCM model that includes only ozonolysis of unsaturated organic compounds and $\mathrm{OH}$ oxidation of acetylene, when we updated yields of ozonolysis of alkenes and included $\mathrm{OH}$ oxidation of isoprene, vinyl alcohol chemistry, reaction of formaldehyde with $\mathrm{HO}_{2}$, oxidation of aromatics, and reaction of $\mathrm{CH}_{3} \mathrm{O}_{2}$ with $\mathrm{OH}$, the model predictions for formic acid were improved by a factor of 6.4 in UBWOS 2013 and 4.5 in CalNex, respectively. A comparison of measured and modeled $\mathrm{HCOOH} /$ acetone ratios is used to evaluate the model performance for formic acid. We conclude that the modified chemical mechanism can explain 19 and $45 \%$ of secondary formation of formic acid in UBWOS 2013 and CalNex, respectively. The contributions from aqueous reactions in aerosol and heterogeneous reactions on aerosol surface to formic acid are estimated to be $0-$ 6 and $0-5 \%$ in UBWOS 2013 and CalNex, respectively. We observe that air-snow exchange processes and morning fog 
events may also contribute to ambient formic acid concentrations during UBWOS 2013 ( $\sim 20 \%$ in total). In total, 53-59 in UBWOS 2013 and 50-55 \% in CalNex of secondary formation of formic acid remains unexplained. More work on formic acid formation pathways is needed to reduce the uncertainties in the sources and budget of formic acid and to narrow the gaps between measurements and model results.

\section{Introduction}

Carboxylic acids are present in the gaseous phase, aqueous phase and in particles (Chebbi and Carlier, 1996). They are significant contributors to rain acidity in remote environments (16-65\%) and they regulate aqueous reactions with pH-dependence in cloud (Khare et al., 1999; Vet et al., 2014). Some higher carboxylic acids are proposed to enhance new particle formation in the atmosphere (Zhang et al., 2004). These organic acids also play important roles in secondary organic aerosol (SOA) formation (Carlton et al., 2006). Research on the sources and sinks of carboxylic acids is needed to understand the processes in acid rain, new particle formation and SOA formation, all of which are integral to our understanding of regional air quality and climate change.

Formic acid $(\mathrm{HCOOH})$ is the simplest organic acid and is one of the most abundant carboxylic acids detected in the atmosphere (Khare et al., 1999). The sources of formic acid are emissions from vehicle exhausts (Kawamura et al., 2000), biomass burning (Akagi et al., 2011), biogenic activities (Jardine et al., 2011), and secondary formation from the oxidation of volatile organic compounds (VOCs) (Khare et al., 1999), e.g., oxidation of alkenes by ozone (Neeb et al., 1997). Aqueous reactions of formaldehyde (Chameides and Davis, 1983), glyoxal (Carlton et al., 2007) and other species also produce formic acid. Previous studies have proposed that organic aerosol aging by heterogeneous reactions with $\mathrm{OH}$ radicals is also an important source of formic acid (Molina et al., 2004; Paulot et al., 2011). The global sources of formic acid are thought to be dominated by photochemical oxidation of biogenic VOCs (Paulot et al., 2011). Recent work also indicated that secondary formation was the largest contributor to formic acid in polluted air in the summertime (de Gouw et al., 2005; Veres et al., 2011), even though primary emissions may account for a larger fraction in the wintertime (Bannan et al., 2014). Thus, studies focused on secondary formation of formic acid will be helpful to better understand the oxidation chemistry of anthropogenic and biogenic VOCs (Paulot et al., 2011). While dominantly present in the gas phase, formic acid appears to be present in aerosols at higher than expected concentrations (Liu et al., 2012; Yatavelli et al., 2014), although instrument artifacts might play a role in those measurements.

The diversity of emission sources, formation pathways and precursors of formic acid makes it challenging to fully un- derstand its primary sources and secondary formation in the atmosphere. Modeling studies showed that observed formic acid concentrations in both urban plumes (Le Breton et al., 2014) and biogenically dominated areas (Paulot et al., 2011) could not be explained by current chemical mechanisms (Table S1 in the Supplement). Comparisons between satellite measurements and global three-dimensional modeling results indicate that formic acid is underpredicted in many regions of the world, especially in tropical and boreal forests (Stavrakou et al., 2012), in the summertime and over biomass burning regions (Cady-Pereira et al., 2014). To address this underestimation, many new formation pathways for formic acid have been proposed in recent years, such as $\mathrm{OH}$ oxidation of isoprene (Paulot et al., 2009b) and formation from vinyl alcohol (Andrews et al., 2012).

In this study, we show that formic acid concentrations are at comparable levels in two different environments: (1) an urban downwind site and (2) a site in an oil and gas producing region, even though the VOC composition is completely different. A box model constrained by measurements will be used to simulate the secondary formation of formic acid and to evaluate the recently proposed formation pathways of formic acid. Contributions from condensed phase sources of formic acid will also be investigated.

\section{Measurements and methods}

\subsection{UBWOS campaigns}

Data sets collected from ground sites in three different campaigns are used in this study: Horse Pool during the Uintah Basin Winter Ozone Studies (UBWOS) in 2012 and 2013 (Edwards et al., 2013) and Pasadena ground site during the California Research at the Nexus of Air Quality and Climate Change (CalNex) campaign in 2010 (Ryerson et al., 2013).

Two campaigns at the Horse Pool site $\left(40.1428^{\circ} \mathrm{N}\right.$, $109.4680^{\circ} \mathrm{W}$ ) in the Uintah Basin, Utah, were conducted in January-February 2012 and 2013, respectively. The Uintah Basin, where over 10000 active oil and gas wells are located, has started to experience severe ozone problems during wintertime in recent years. Measurements in 2012 occurred from 15 January to 29 February but no ozone episode was encountered, due to unusually warm conditions and a lack of ground snow cover (Edwards et al., 2013). The second campaign was performed from 25 January to 22 February 2013 and very high ozone concentrations were observed during this campaign (Edwards et al., 2014). This work will focus on the data set collected during the 2013 study, since secondary formation of formic acid was more prominent than during the 2012 study.

In the two UBWOS campaigns, formic acid in the ambient air was measured using negative-ion proton-transfer chemical ionization mass spectrometry (NI-PT-CIMS) using acetate $\left(\mathrm{CH}_{3} \mathrm{COO}^{-}\right)$as the reagent ion (Veres et al., 2008). 
Calibrations of formic acid were performed in the field using diluted gas standards generated from permeation tubes. Formic acid concentrations of these sources were determined by catalytically converting to $\mathrm{CO}_{2}$ and subsequently measuring using a $\mathrm{CO}_{2}$ detector (Veres et al., 2010). Instrument backgrounds were measured every $2-3 \mathrm{~h}$ by passing ambient air through a platinum $(\mathrm{Pt})$ catalytic converter maintained at $350^{\circ} \mathrm{C}$. Measurement accuracy of formic acid using NIPT-CIMS is estimated to be better than $25 \%$, propagated from the uncertainties of permeation tube concentrations, calibration and variations of background signals. Nitric acid $\left(\mathrm{HNO}_{3}\right)$ was also measured by NI-PT-CIMS during UBWOS 2013.

During UBWOS 2013, C2-C7 alkanes, C2-C3 alkenes, acetylene and benzene were measured by a gas chromatograph with flame ionization detection (GC-FID) (Bon et al., 2011). Aromatics and selected oxygenates were measured by a proton transfer reaction mass spectrometer (PTR-MS). A custom-built four-channel cavity ring-down spectrometry instrument $\left(\mathrm{NO}_{\mathrm{x}}-\mathrm{CaRD}\right)$ was used to measure ozone $\left(\mathrm{O}_{3}\right)$ and nitrogen oxides $\left(\mathrm{NO}_{\mathrm{x}}\right.$, including $\mathrm{NO}$ and $\left.\mathrm{NO}_{2}\right)$ (Wild et al., 2014). PANs (peroxycarboxylic nitric anhydrides) and nitryl chloride $\left(\mathrm{CINO}_{2}\right)$ were measured by a CIMS with iodide $\left(\mathrm{I}^{-}\right)$as the reagent ion (Slusher et al., 2004). A cavity ring-down spectroscopy system was used to detect nighttime $\mathrm{NO}_{3}$ and $\mathrm{N}_{2} \mathrm{O}_{5}$ in the atmosphere (Dubé et al., 2006). Methane was measured by a commercial cavity ring-down spectrometry instrument (Picarro G2301). A scanning mobility particle sizer (SMPS, TSI model 3081) and an aerodynamic particle size (APS, TSI model 3321) were used to measure the number-size distribution of aerosols. Filter samples were collected and analyzed by a Sunset Laboratory thermal/optical analyzer for organic carbon (OC) and by ion chromatography (IC) for nitrate, sulfate, ammonium and chloride. Measurement of meteorological parameters, including temperature, relative humidity, wind direction, wind speed, precipitation, downwelling and upwelling solar radiation were made at the Horse Pool site by NOAA ESRL PSD. During UBWOS 2013, the Uintah Basin was covered by snow with an average depth of $14 \pm 4 \mathrm{~cm}$. Snow samples were collected (top $5 \mathrm{~cm}$ ) and the chemical composition in snow was measured by ion chromatography from melted snow water.

To assist data interpretation in this study, some measurements from UBWOS 2012 will also be used. During UBWOS 2012, C2-C10 hydrocarbons and many oxygenates were measured by an online two-channel gas chromatograph mass spectrometer (GC-MS) (Gilman et al., 2013). Additionally, photolysis frequencies of $\mathrm{O}_{3}$ and $\mathrm{NO}_{2}$ were measured by a filter radiometer only during the 2012 campaign. Therefore, the aforementioned 2012 data will be used to estimate unmeasured concentrations of some hydrocarbons and photolysis frequencies during the 2013 study.

\subsection{CalNex 2010 campaign}

Measurements at the Pasadena site during CalNex were conducted from 15 May to 15 June 2010 on the campus of the California Institute of Technology (34.1406 N, 118.1225 W). The measurements at this site sampled outflow from Los Angeles (LA). A suite of state-of-the-art instruments was deployed at the Pasadena site (Ryerson et al., 2013).

During CalNex, the same NI-PT-CIMS instrument as in the UBWOS campaigns was used to measure formic acid; the CalNex data set has been previously reported by Veres et al. (2011). Measurements of hydrocarbons and oxygenates were performed by online GC-MS (Gilman et al., 2013) and proton-transfer-reaction ion-trap mass spectrometry (PIT-MS) (Warneke et al., 2005). An analyzer based on the Hantzsch reaction was used to measure formaldehyde (HCHO) (Warneke et al., 2011). $\mathrm{NO}_{\mathrm{x}}\left(\mathrm{NO}\right.$ and $\mathrm{NO}_{2}$ ) and ozone were measured by commercial chemiluminescence gas analyzers (Thermo 42i-TL and 42i-TL with blue light converter) and a UV absorbance analyzer (Thermo 49c), respectively. Photolysis frequencies of $\mathrm{NO}_{2}$ were derived from filter radiometer measurements. A particle into liquid sampler (PILS) coupled with a total organic carbon (TOC) analyzer was used to measure water-soluble organic carbon (WSOC) (Zhang et al., 2012). Aerosol size distributions were measured by an SMPS (TSI model 3936).

\subsection{Description of box model}

The Dynamically Simple Model of Atmospheric Chemical Complexity (DSMACC) (Emmerson and Evans, 2009) is used to simulate secondary formation of formic acid in this study. Hydrocarbons, $\mathrm{NO}_{\mathrm{x}}$ (including $\mathrm{NO}_{3}$ and $\mathrm{N}_{2} \mathrm{O}_{5}$ ), ozone, methane, and formaldehyde are constrained to their average measured diurnal profiles throughout the simulation period of the zero-dimensional box model for each campaign, and the box model is run toward a diurnal steady state (DSS). Unmeasured VOC species during UBWOS 2013 are calculated from VOCs measured in 2013 and their respective enhancement ratio measured in 2012. The VOC pairs used for the calculations are generally chosen to have similar reactivity and/or similar structures. For example, 2methylpentane in 2013 is calculated from $n$-hexane concentrations measured in 2013 and the 2-methylpentane / nhexane ratios measured in 2012. Photolysis frequencies are also scaled from the 2012 measurements and the inferred surface albedo from measurements of downwelling and upwelling solar radiations (see Edwards et al. (2014) for details).

The model is typically run for 10 days, after which the simulated diurnal profiles of formic acid and other photochemical products (e.g., acetaldehyde and acetone) change little compared to the previous day (Edwards et al., 2013) (Fig. S2). Modeled diurnal profiles of formic acid and other related species (mainly acetone) in the last day will be shown 
in this study. We note that primary emissions of formic acid and other photochemical products (e.g., acetone) are not prescribed in the box model. The box model output will be compared to the calculated secondary concentrations by subtracting the primary part. Chemical mechanisms for measured VOC species and other inorganic species are extracted from the Master Chemical Mechanism (MCM) v3.2 website (http://mcm.leeds.ac.uk/MCM) (Jenkin et al., 2012). $\mathrm{ClNO}_{2}$ chemistry is included in MCM v3.2 and measured cycloalkanes are lumped into cyclohexane (the only cycloalkane in MCM v3.2), following previous work (Edwards et al., 2013). A first-order physical loss term is used in the box model to characterize the processes of dilution due to mixing with background air and/or deposition. A physical loss rate of $1.15 \times 10^{-5} \mathrm{~s}^{-1}$, corresponding to a lifetime of $24 \mathrm{~h}$, is applied in the model runs for both campaigns. This lifetime due to physical losses is consistent with the setup used in simulations of other similar box models (e.g.,Edwards et al., 2013; Li et al., 2014; Fried et al., 2008, 2003). A sensitivity study for physical loss rates in the box model will be performed (Sect. 3.4).

\section{Results and discussions}

\subsection{Comparisons of formic acid in two different campaigns}

Figure 1 shows the measured concentrations of formic acid from the CalNex and UBWOS campaigns. The average (arithmetic mean) concentrations of formic acid over the entire campaigns were $2.0 \pm 1.0$ and $2.3 \pm 1.3 \mathrm{ppb}$ (parts per billion) in CalNex and UBWOS 2013, respectively. Similar concentration ranges (from sub-ppb level to 8-10 ppb) were observed during the two campaigns. Diurnal variations of formic acid during the two different campaigns are also shown in Fig. 1. Higher formic acid concentrations are observed during the daytime in both of the campaigns.

In a previous paper, Veres et al. (2011) conducted diurnal profile analyses and correlations of formic acid with other compounds and the authors concluded that formic acid at the Pasadena site in CalNex was dominated by secondary formation. This finding is also valid for the UBWOS 2013 campaign. The evidence includes the following: (1) there were very few concentration spikes in the measured time series of formic acid that would indicate a local, primary source of formic acid. In contrast, concentration spikes of hydrocarbons (e.g., benzene) were detected frequently at the Horse Pool site due to primary emissions from nearby oil and natural gas wells (Fig. S1) (Warneke et al., 2014). Measurements by the PTR-MS in a mobile laboratory sampling downwind oil and gas wells also showed little enhancement of the formic acid signal $\left(\mathrm{m} / \mathrm{z}, 47, \mathrm{HCOOH} \times \mathrm{H}^{+}\right)($Warneke et al., 2014). (2) Multi-day accumulation patterns of formic acid during stagnation events (e.g., 29 January-9 February
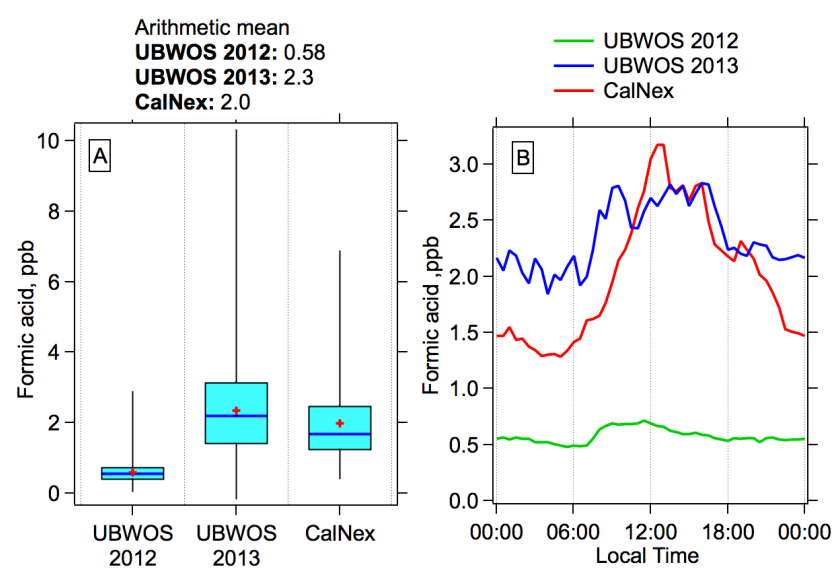

Figure 1. (a) Box-whisker plots of formic acid concentrations in UBWOS 2012, UBWOS 2013 and CalNex. The boxes denote the central $50 \%$ of the data (25-75\%), and the bars within the box indicate the median value. The ends of the whiskers show the maximum and minimum of the data. The cross markers show arithmetic mean concentrations of formic acid. (b) Diurnal variations (arithmetic mean) of formic acid in UBWOS 2012, UBWOS 2013 and CalNex.

2013) are most similar to species with predominantly secondary sources (e.g., acetone and ozone) but are different from species with primary emissions (e.g., benzene) (Fig. 2). (3) Formic acid during UBWOS 2013 increased by a factor of 4 compared to measurements in UBWOS 2012 when photochemistry was weak (Edwards et al., 2013). Most hydrocarbons showed enhancements in 2013 from 2012 by a factor of 2-3, due to shallower boundary layer heights in 2013 and more stagnant meteorological conditions. The different enhancements observed between primary species and secondary products from 2012 to 2013 reflect the fact that primary compounds are affected linearly by mixing and dilution processes in the boundary layer, whereas photochemical formation of secondary products is non-linear.

The dominance of secondary formation for formic acid makes it hard to accurately estimate the contribution from primary sources. The potential primary sources of formic acid in CalNex are mainly vehicular emissions. In addition to vehicular emissions, other combustion sources related to oil and gas extractions, e.g., compressors, dehydrators and pump jacks, can also contribute to primary emissions of formic acid in UBWOS campaigns. As shown in Table 1, large ranges of emission ratios of formic acid to combustion tracers are reported in the literature. Bannan et al. (2014) reported a $\mathrm{HCOOH} / \mathrm{CO}$ emission ratio of $1.2 \mathrm{ppbpm}^{-1}$ (parts per million) based on wintertime observations in London, whereas no direct emissions of formic acid were detected in the northeastern USA (de Gouw et al., 2005). The most comprehensive and latest study showed that $\mathrm{HCOOH} / \mathrm{CO}$ emission ratios from gasoline vehicles are 42.2 \pm 30.0 during hot running and $10.2 \pm 6.5 \times 10^{-3} \mathrm{ppb}^{\mathrm{ppm}}{ }^{-1}$ during cold start 
Table 1. Emission ratios (ERs) of formic acid to anthropogenic tracers from combustion emissions reported in the literature.

\begin{tabular}{lrll}
\hline Pairs & $\begin{array}{r}\text { Emission } \\
\text { ratios, } \\
\text { ppb ppm }^{-1}\end{array}$ & Location & References \\
\hline $\mathrm{HCOOH} / \mathrm{CO}$ & 0.21 & Virginia, USA & Talbot et al. (1988) \\
$\mathrm{HCOOH} / \mathrm{CO}$ & 1.22 & London, UK & Bannan et al. (2014) \\
$\mathrm{HCOOH} / \mathrm{NO}_{\mathrm{x}}$ & 8.35 & London, UK & (Bannan et al., (2014) \\
$\mathrm{HCOOH} / \mathrm{C}_{2} \mathrm{H}_{2}$ & 0 & Northeastern USA & de Gouw et al. (2005) \\
$\mathrm{HCOOH} / \mathrm{CO}$ & $42.2 \pm 33.0$ & Laboratory study in California & Crisp et al. (2014) \\
& $\times 10^{-3}$ & (hot running) & \\
$\mathrm{HCOOH} / \mathrm{CO}$ & $10.2 \pm 6.5$ & Laboratory study in California \\
& $\times 10^{-3}$ & Crisp et al. (2014) & \\
& & & \\
\hline
\end{tabular}

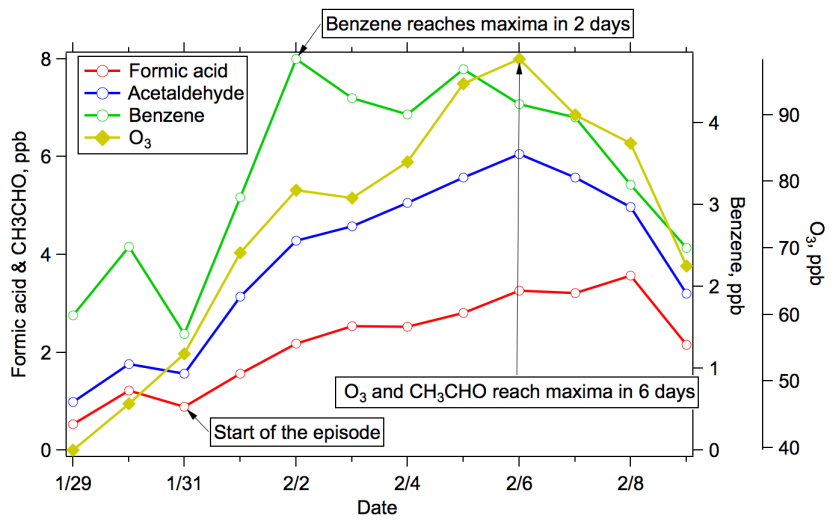

Figure 2. Buildup patterns of formic acid, acetaldehyde, benzene and ozone in 29 January-9 February in UBWOS 2013. Daily averages of various species are shown.

(Crisp et al., 2014). Here, the $\mathrm{HCOOH} / \mathrm{CO}$ emission ratios $\left(42.2 \pm 30.0 \times 10^{-3} \mathrm{ppb} \mathrm{ppm}^{-1}\right)$ obtained in Crisp

et al. (2014) for gasoline vehicles during hot running are used to determine primary contributions to formic acid in the two campaigns. For UBWOS, we note the caveat that $\mathrm{HCOOH} / \mathrm{CO}$ emission ratios related to oil and gas extractions may be different from those in urban regions. Because $\mathrm{CO}$ was not measured during UBWOS 2013, acetylene $\left(\mathrm{C}_{2} \mathrm{H}_{2}\right)$, another common combustion tracer, is used instead for the analysis. Utilizing the emission ratio of $5.78 \mathrm{ppb} \mathrm{ppm}^{-1}$ for $\mathrm{C}_{2} \mathrm{H}_{2} / \mathrm{CO}$ at the Pasadena site (Borbon et al., 2013), the emission ratios of $\mathrm{HCOOH} / \mathrm{C}_{2} \mathrm{H}_{2}$ from combustion source are calculated. Formic acid concentrations from combustion sources are determined from the $\mathrm{HCOOH} / \mathrm{C}_{2} \mathrm{H}_{2}$ emission ratio and the measured acetylene concentrations. The calculations show that emissions from combustion sources only accounted for $0.46 \pm 0.32$ and $0.63 \pm 0.45 \%$ of formic acid in CalNex and UBWOS 2013, respectively. This shows that primary emissions only contributed very minor parts to formic acid concentrations in both CalNex and UBWOS 2013. Using the same procedure, we determine that primary emissions from combustion sources accounted for $1.0 \pm 0.7 \%$ of formic acid in UBWOS 2012, although photochemistry was weaker in 2012 compared to 2013.

Ozonolysis of unsaturated species and $\mathrm{OH}$ oxidation of acetylene are included as the only two formation pathways for formic acid in most previous modeling studies (Le Breton et al., 2012, 2014; Ito et al., 2007), as well as in MCM v3.2. Acetylene is a ubiquitous species in the atmosphere, but the reaction of acetylene with $\mathrm{OH}$ radicals is rather slow $\left(k_{\mathrm{OH}}=\right.$ $7.8 \times 10^{-13} \mathrm{~cm}^{3}$ molecule ${ }^{-1} \mathrm{~s}^{-1}, 298 \mathrm{~K}$ and 1 bar) (Atkinson et al., 2006). Thus, unsaturated species are the most important precursors of formic acid in MCM v3.2 in polluted environments. Figure 3 shows the measured concentration ratios of various VOCs in the UBWOS campaigns (2012 and 2013) relative to those measured in CalNex. The concentrations of alkanes were much higher (5-60 times) in the UBWOS campaigns than in CalNex, mainly due to large emissions from oil and gas production in the Uintah Basin (Helmig et al., 2014). In contrast, levels of alkene and other unsaturated species were much lower in UBWOS than those in CalNex, especially for biogenic species (e.g., isoprene and its oxidation products). Aromatics are generally higher for UBWOS compared to CalNex. Thus, the much lower concentrations of alkenes and other unsaturated species in UBWOS 2013 compared to CalNex would imply a lower formic acid concentration in UBWOS 2013 if alkene ozonolysis was the main secondary formation pathway. However, formic acid levels are similar at the two different locations. This disagreement between measurements and expectation from known chemistry will be investigated using the box model described in Sect. 2.3.

\subsection{Base box model run}

MCM v3.2 was extracted from the official website (http: $/ / \mathrm{mcm}$.leeds.ac.uk/MCM) and used in the box model. This run is referred to as the base case. The modeled formic acid diurnal steady state concentrations for UBWOS 2013 and CalNex are shown in Fig. 4 (also Fig. S2). Modeled average formic acid concentrations are $0.05 \pm 0.003$ and 


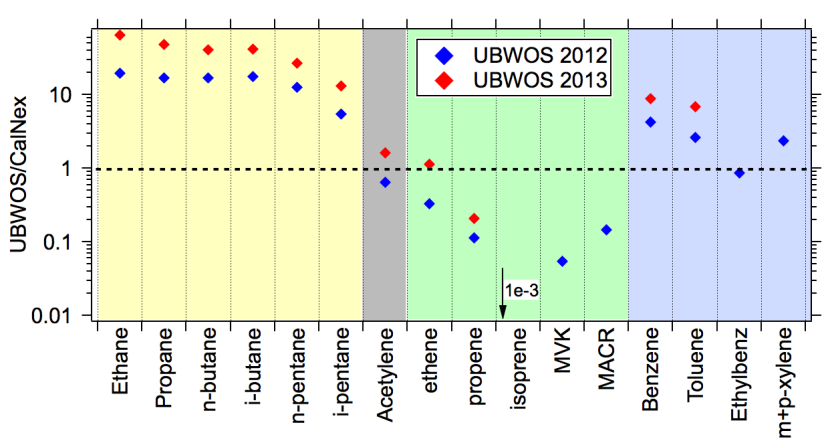

Figure 3. Ratios of average concentrations of various VOCs in UBWOS 2012 and UBWOS 2013 relative to CalNex. The dashed line indicates a ratio of unity.

$0.18 \pm 0.02 \mathrm{ppb}$ for UBWOS 2013 and CalNex, respectively. The higher modeled formic acid concentrations in CalNex are consistent with higher levels of alkenes that react with ozone to produce formic acid. However, the modeled formic acid concentrations are 40 and 13 times lower than the measurements for UBWOS 2013 and CalNex, respectively. Modeled formic acid concentrations are higher in the daytime and lower at night, as expected. But, the modeled formic acid concentrations are highest in late afternoon (around 18:00 LT - local time) for both campaigns, in contrast to the measurements that show broad afternoon peaks. This is mainly due to the constant physical loss rates that are used to represent the processes of dilution and deposition. The transport of air masses from downtown of Los Angeles to the Pasadena site during noontime (10:00-14:00 LT) (Veres et al., 2011) could be another reason for the different peak times between measurements and model results in CalNex. This issue about diurnal profile patterns in the box model will be discussed again in Sect. 3.4.

\subsection{Modifications to MCM mechanisms}

To investigate the large underestimation of formic acid concentration in the base model run, a thorough examination of MCM v3.2 and a literature review for formation pathways of formic acid have been conducted. Based on these results, the following are some recent findings incorporated in the box model.

1. Formic acid yields of ozonolysis of alkenes and other unsaturated species in MCM v3.2 are compared with literature values (Table 2). Even though production of formic acid from ozonolysis of these unsaturated compounds is represented in MCM v3.2, the yields in MCM v3.2 are lower than literature values by various factors (as high as $77 \%$ for methyl vinyl ketone, MVK), with the exception of $\beta$-pinene. Formation of formic acid from $\mathrm{O}_{3}$ oxidation occurs via reaction of Criegee intermediate (CI) biradicals with $\mathrm{H}_{2} \mathrm{O}$. The $\mathrm{CH}_{2} \mathrm{OO}$ radical also reacts with $\mathrm{CO}, \mathrm{SO}_{2}, \mathrm{NO}$ and $\mathrm{NO}_{2}$, which
Table 2. Yields of formic acid from reactions of alkenes and other unsaturated compounds with ozone and $\mathrm{OH}$ radicals.

\begin{tabular}{lrrr}
\hline Species & $\begin{array}{r}\text { Literature } \\
\text { values }\end{array}$ & $\begin{array}{r}\text { MCM } \\
\text { v3.2 }\end{array}$ & $\begin{array}{r}\text { Modified MCM } \\
\mathrm{v} 3.2\end{array}$ \\
\hline Reaction with ozone & & & \\
\hline Ethene & $0.41^{1}$ & 0.23 & 0.34 \\
Propene & $0.14^{2}$ & 0.074 & 0.14 \\
Isobutene & $0.13^{2}$ & 0.056 & 0.13 \\
Isoprene & $0.30^{2}$ & 0.15 & 0.31 \\
MVK & $0.32^{3}$ & 0.074 & 0.31 \\
MACR & $0.22^{3}$ & 0.20 & - \\
$\alpha$-pinene & $0.075^{4}$ & 0 & - \\
$\beta$-pinene & $0.04^{4}$ & 0.09 & \\
\hline Reaction with OH & & & 0.08 \\
\hline Isoprene & $0.10^{5}$ & 0 & 0.18 \\
Glycolaldehyde & $0.18^{6}$ & 0 & 0.08 \\
Hydroxyacetone & $0.08^{7}$ & 0 & - \\
$\beta$-pinene & $0.02^{8}$ & 0 & 0.36 \\
Acetylene & $0.40^{9}$ & 0.36 & \\
\hline
\end{tabular}

"-" indicates there is no modification to chemical mechanism of the species. References in the table: (1) Leather et al. (2012); (2) Neeb et al. (1997); (3) Grosjean et al. (1993); (4) Lee et al. (2006); (5) Paulot et al. (2009a); (6) Butkovskaya et al. (2006a); (7) Butkovskaya et al. (2006b); (8) Orlando et al. (2000); (9) Hatakeyama et al. (1986).

compete with the formation of formic acid. $\mathrm{CH}_{2} \mathrm{OO}$ is formed from seven excited biradicals (CHOOA, CHOOB, CHOOC, CHOOD, CHOOE, CHOOF and CHOOG), which originate from different alkenes and unsaturated compounds based on the degree of alkyl substitution (Saunders et al., 2003). These excited biradicals undergo decomposition (producing $\mathrm{CO}, \mathrm{HO}_{2}$ and $\mathrm{OH}$ ), isomerization (producing $\mathrm{CO}$ and $\mathrm{H}_{2} \mathrm{O}$ ) or stabilization (producing $\mathrm{CH}_{2} \mathrm{OO}$ ). The branching ratios among decomposition, isomerization and stabilization determine the yields of formic acid from the seven different groups of species (Table S2). Branching ratios of the three pathways from seven excited biradicals in MCM v3.2 are modified either using values reported in literature when available (such as for ethene; Alam et al., 2011), or by matching yields in the modified MCM with the reported yields in the literature (Table S2). The yield of methacrolein (MACR) is not modified since the difference $(10 \%)$ between the yields in the literature and in MCM v3.2 is small. The yields of the two monoterpenes ( $\alpha$-pinene and $\beta$-pinene) also remain unchanged since the two compounds were at low levels in both campaigns ( $45 \pm 40 \mathrm{ppt}$ in CalNex, below detection limit in UBWOS). The overestimated yield for $\beta$ pinene and underestimated yield for $\alpha$-pinene also partially cancel out the differences. It should be noted that the modifications of branching ratios here also affect the 
yields of other products (e.g., formaldehyde) and use of these numbers determined here in other studies should be done with caution. It is not an issue in this study, as formaldehyde has been constrained using measurements.

2. $\mathrm{OH}$ oxidation of isoprene and the subsequent products can lead to formation of formic acid, but this is not included in MCM v3.2 (Table 2). A recent chamber study showed that $\mathrm{OH}$ oxidation of isoprene forms formic acid with a yield of $10 \%$, with a significant share of the yield attributed to the oxidation of glycolaldehyde and hydroxyacetone (Paulot et al., 2009a). Earlier studies also showed that formic acid is formed from photooxidation of glycolaldehyde (Butkovskaya et al., 2006a) and hydroxyacetone (Butkovskaya et al., 2006b) with yields of 18 and $8 \%$, respectively. However, the findings of glycolaldehyde and hydroxyacetone as precursors of formic acid are questioned by another study (Orlando et al., 2012). Other second-generation reactions may also contribute to formic acid formation, including $\delta$-hydroxy isoprene nitrates (Paulot et al., 2009a), hydroperoxy methylbutenals (HPALDs) (Stavrakou et al., 2012) and epoxides (IEPOX) (Bates et al., 2014). Considering the complexity of isoprene chemistry, a detailed update of isoprene chemistry that includes all secondary reactions producing formic acid was beyond the scope of this study. Alternatively, the reported effective yield of formic acid from isoprene photooxidation in Paulot et al. (2009a) is used as the benchmark. After including the formation of formic acid from $\mathrm{OH}$ oxidation of glycolaldehyde and hydroxyacetone in MCM v3.2 to match the reported yields in Butkovskaya et al. $(2006 \mathrm{a}, \mathrm{b})$, the effective yield of formic acid from isoprene oxidation in the modified MCM v3.2 is $8 \%$, which is slightly lower than the reported value $(10 \%)$ in Paulot et al. (2009a). OH oxidation of $\beta$-pinene and acetylene show only small differences between the literature values and MCM v3.2, and therefore no change is made for these two species. The modifications of $\mathrm{O}_{3}$ and $\mathrm{OH}$ oxidation of alkenes and other unsaturated species discussed above will be referred to as the "modified alkenes" case.

3. Vinyl alcohol $\left(\mathrm{CH}_{2}=\mathrm{CHOH}\right)$ has been suggested to be a precursor of formic acid when it is oxidized by OH radicals (Archibald et al., 2007; So et al., 2014). Vinyl alcohol is formed through tautomerization of acetaldehyde by photolysis (Andrews et al., 2012). Organic acids (da Silva, 2010) and inorganic acids (Karton, 2014) can catalyze the tautomerization processes between acetaldehyde and vinyl alcohol. Here, both photo-induced and organic-acids catalyzed tautomerization are incorporated in the box model (Table S3). The tautomerization catalyzed by inorganic acids is not included since the rate coefficients are not available. In
MCM v3.2, vinyl alcohol is produced from the photolysis of 3-hydroxy-cyclohexanone and it further reacts with $\mathrm{OH}$ to form glycolaldehyde and an $\mathrm{HO}_{2}$ radical In this study, the oxidation mechanisms of vinyl alcohol proposed by Archibald et al. (2007) and So et al. (2014) are used in place of the MCM v3.2 default with the two cases referred to as "VINOH from Archibald" and "VI$\mathrm{NOH}$ from So", respectively.

4. Reactions of $\mathrm{HOCH}_{2} \mathrm{OO}$, a product from the reaction of formaldehyde $(\mathrm{HCHO})$ with $\mathrm{HO}_{2}$ radicals, also contribute to formic acid formation (Jenkin et al., 2007; Atkinson et al., 2006). The equilibrium constant between $\mathrm{HOCH}_{2} \mathrm{OO}$ and $\mathrm{HCHO}+\mathrm{HO}_{2}(5.3 \times$ $10^{-16} \mathrm{~cm}^{3}$ molecule ${ }^{-1}$ at $298 \mathrm{~K}$ and $1.6 \times 10^{-14} \mathrm{~cm}^{3}$ molecule ${ }^{-1}$ at $263 \mathrm{~K}$ ) is much larger at low temperature (Atkinson et al., 2006). As a result, the reactions of $\mathrm{HOCH}_{2} \mathrm{OO}$ are more important during UBWOS 2013 due to the low ambient temperatures $\left(-8.0 \pm 4.0^{\circ} \mathrm{C}\right)$. This modification is referred to as the " $\mathrm{HCHO} / \mathrm{HO}_{2}$ " case.

5. Many studies have shown that formic acid is formed from $\mathrm{OH}$ oxidation of aromatics (Berndt et al., 1999; Berndt and Böge, 2001; Baltensperger et al., 2005; Wyche et al., 2009) (Table S4). The reported yields of formic acid range from 2 to $13 \%$ for various aromatics. The yields found in the literature are highly variable, not only among different species, but also for a single species (e.g., 1,3,5-trimethylbenzene). Formic acid is not treated as a product from oxidation of aromatics in MCM v3.2. Here, a yield of $10 \%$ is applied to all of the aromatics included in MCM v3.2. We note that the yields used here for aromatics should be near an upper limit under real atmospheric conditions. This modification will be referred to as the "modified aromatics" case.

6. Several studies have proposed that the reaction of $\mathrm{CH}_{3} \mathrm{O}_{2}$ with $\mathrm{OH}$ might be an important source of formic acid (Archibald et al., 2009; Fittschen et al., 2014). A recent measurement confirms that this reaction can occur with a relatively high rate constant $(2.8 \pm 1.4 \times$ $10^{-10} \mathrm{~cm}^{3}$ molecule $\mathrm{s}^{-1} \mathrm{~s}^{-1}$ ) (Bossolasco et al., 2014). Reaction of $\mathrm{CH}_{3} \mathrm{O}_{2}$ with $\mathrm{OH}$ radicals may proceed in three pathways with different products: $\mathrm{CH}_{2} \mathrm{O}_{2}+\mathrm{H}_{2} \mathrm{O}$, $\mathrm{CH}_{3} \mathrm{O}+\mathrm{HO}_{2}$ and $\mathrm{CH}_{3} \mathrm{OH}+\mathrm{O}_{2}$. Formic acid production from $\mathrm{CH}_{2} \mathrm{O}_{2}$ radicals only occurs via the first of those three pathways. The branching ratio to the first pathway ranges between 49 (Maricq et al., 1994) and $91 \%$ (Daele and Poulet, 1996), both based on branching ratio measurements for the reaction of $\mathrm{CH}_{3} \mathrm{O}_{2}$ with chlorine radicals $(\mathrm{Cl})$ as reference for the respective $\mathrm{OH}$ reaction. Here, a unity branching ratio was used to simulate the upper limit of the contribution from this reaction to formic acid. This modification will be referred to as the " $\mathrm{CH}_{3} \mathrm{O}_{2}$ " case. 
The only chemical sink of formic acid in MCM v3.2 is the reaction with the $\mathrm{OH}$ radical $\left(k_{\mathrm{OH}}=4.5 \times\right.$ $10^{-13} \mathrm{~cm}^{3}$ molecule $\mathrm{s}^{-1} \mathrm{~s}^{-1}$, independent of temperature). A recent study proposed that formic acid reacts with Criegee radicals with rate coefficients in excess of $1 \times$ $10^{-10} \mathrm{~cm}^{3}$ molecule ${ }^{-1} \mathrm{~s}^{-1}$ (Welz et al., 2014). All of the cases examined here include reaction with $\mathrm{OH}$ radicals as the sole chemical loss pathway. A sensitivity test to the newly proposed sink due to Criegee radicals will be conducted separately.

Simulated results from the six modified cases are shown in Fig. 4 (for magnified lower ranges of the plots, refer to Fig. S3). For UBWOS 2013, the biggest improvement to the modeled formic acid concentration comes from the inclusion of aromatics as precursors of formic acid. Other modified cases in UBWOS 2013 somewhat increase formic acid concentrations, but to a much smaller extent. Unlike UBWOS 2013, modifications to the alkene mechanisms, inclusion of aromatics as precursors and one variant of vinyl alcohol chemistry significantly enhance the modeled formic acid concentrations during the CalNex study.

The different responses of modeled formic acid to various formation pathways in UBWOS and CalNex are due to the different environments and VOC emission patterns in the two campaigns. The vinyl alcohol oxidation mechanism proposed by So et al. (2014) results in larger formic acid production than when using the mechanism proposed by Archibald et al. (2007), because So et al. (2014) estimated a much higher rate constant for the reaction of vinyl alcohol with $\mathrm{OH}$ radicals $\left(k_{\mathrm{OH}}=6.8 \times 10^{-11}\right.$ at $298 \mathrm{~K}$ vs. $k_{\mathrm{OH}}=$ $6.0 \times 10^{-12} \mathrm{~cm}^{3}$ molecule $\mathrm{s}^{-1}$ by Archibald et al., 2007). The contribution of vinyl alcohol chemistry to formic acid formation in CalNex is noticeably larger than for UBWOS 2013, since modeled OH concentrations during CalNex are higher $\left(1.5 \times 10^{6}\right.$ vs. $2.9 \times 10^{5}$ molecule $\mathrm{cm}^{-3}$ in UBWOS $2013,24 \mathrm{~h}$ average) and therefore $\mathrm{OH}$ oxidation of vinyl alcohol is more competitive with the tautomerization processes back to acetaldehyde. The modest contribution of vinyl alcohol to formic acid formation in the two campaigns is consistent with a simple calculation from a global-scale perspective (Muller and Peeters, 2014). The $\mathrm{HCHO}+\mathrm{HO}_{2}$ reaction slightly increases the modeled formic acid concentration during UBWOS 2013, but only contributes a very small amount in CalNex because of the higher ambient temperatures in Los Angeles $\left(18.4 \pm 4.6^{\circ} \mathrm{C}\right)$. The reaction of $\mathrm{CH}_{3} \mathrm{O}_{2}$ with $\mathrm{OH}$ is not an important contributor to formic acid in either campaign, because the dominant sink of $\mathrm{CH}_{3} \mathrm{O}_{2}$ is through reaction with $\mathrm{NO}$ and $\mathrm{NO}_{2}$ at the observed $\mathrm{NO}_{\mathrm{x}}$ levels $(4.3 \pm 4.1$ in UBWOS 2013 and $14.8 \pm 8.6 \mathrm{ppb}$ in CalNex) during the two campaigns. However, this reaction could provide a persistent source for formic acid, as $\mathrm{CH}_{3} \mathrm{O}_{2}$ is produced through reaction of methane with $\mathrm{OH}$ radicals.

All of the modified cases for formation pathways of formic acid are combined together and the results are also shown in Fig. 4. Note that the oxidation mechanism of vinyl alco-

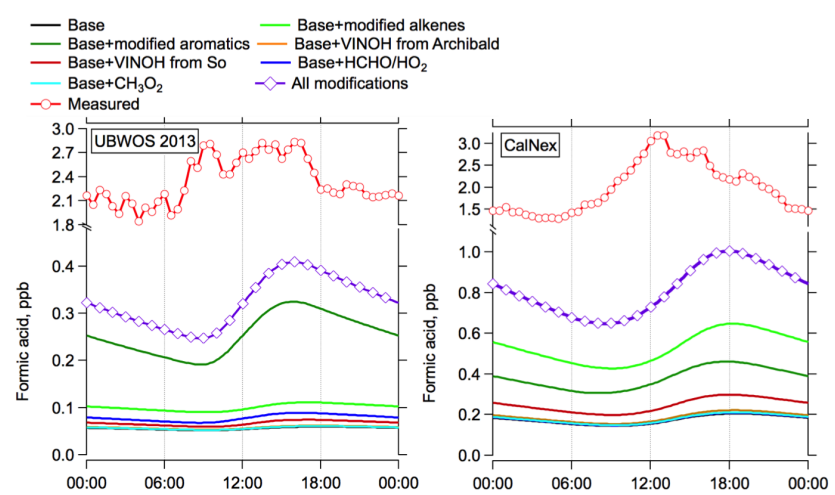

Figure 4. Comparison of measured and modeled diurnal profiles of formic acid for UBWOS 2013 (left) and CalNex (right). A zoom of the figure is shown in Fig. S3. Note that the scales of the $y$ axis are different.

hol from So et al. (2014) is used here, as it is the latest one and the results are based on quantum chemical calculations. Combining all of the modifications in the mechanisms, the modeled formic acid concentrations for UBWOS 2013 and CalNex increase to $0.32 \pm 0.05 \mathrm{ppb}$ and $0.81 \pm 0.12 \mathrm{ppb}$, respectively. Modeled formic acid concentrations are enhanced by a factor of 6.4 in UBWOS 2013 and a factor of 4.5 in CalNex, compared to the base model case in Sect. 3.2. However, despite the large enhancements of modeled formic acid concentrations, these concentrations are still significantly lower than the measurements. A sensitivity model run with the reaction of formic acid with Criegee radicals was conducted in the box model. Inclusion of reactions with Criegee radicals reduces modeled concentrations of formic acid by 20.0 in UBWOS 2013 and $17.4 \%$ in CalNex, which is the combined effect of higher sink and lower formation rates from Criegee radicals. It implies that the discrepancy between measurements and the model may be even higher if the reaction of formic acid with Criegee radicals occurs as proposed.

\subsection{Quantification of box model performance}

For all of the simulations in Sect. 3.3, all of the non-chemical losses due to physical dilution and/or deposition are parameterized using a first-order physical loss rate of $1.15 \times$ $10^{-5} \mathrm{~s}^{-1}$ for formic acid and other species (corresponding to a lifetime of $24 \mathrm{~h}$ due to physical losses). However, atmospheric processes of both turbulent/entrainment mixing with background air and dry deposition are difficult to parameterize and the physical loss rate due to such processes can exhibit large day-to-day and diurnal variations (e.g., due to diurnal changes of boundary layer height). It is also acknowledged that meteorological conditions during UBWOS 2013 and CalNex were quite different, which can result in different physical loss rates.

In order to evaluate the model sensitivity to the physical loss rate in our box model, larger and smaller physical loss 
rates $\left(2.3 \times 10^{-5} \mathrm{~s}^{-1}\right.$ or a lifetime of $12 \mathrm{~h} ; 5.75 \times 10^{-6} \mathrm{~s}^{-1}$ or a lifetime of $48 \mathrm{~h}$ ) were applied in the box model to investigate the model sensitivity to the physical loss rates. As shown in Fig. 5, a longer lifetime due to the physical losses results in larger modeled formic acid, and vice versa. The variation of physical loss rate by a factor of 2 would change the modeled concentrations of formic acid by a factor of 2.0-2.1 in UBWOS 2013 and 2.2-2.3 in CalNex. This phenomenon is consistent with the fact that the sinks of formic acid during both campaigns are dominated by physical losses and that the chemical losses of formic acid are slow. The lifetime of formic acid with respect to reaction with the $\mathrm{OH}$ radical is 87 and 18 days in UBWOS 2013 and CalNex, respectively. The sensitivity tests show that including the reaction with Criegee radicals reduces the lifetime of formic acid with respect to chemical losses to 5.3 days in UBWOS 2013 and 5.4 days in CalNex. In either case, chemical losses of formic acid are slow compared with the physical losses (dilution and deposition) in both campaigns.

As a test of the diurnal steady state (DSS) method using a constant physical loss rate in the box model, an emissionbased box model simulation that utilizes emission rate terms to reproduce concentrations of primary species was conducted for UBWOS 2013 (for details refer to Edwards et al., 2014). A bimodal physical loss rate (higher in daytime and lower at night) is applied to reflect variations in mixing rates with background air at different times of the day. The results of the emission-based box model associated with the modified MCM v3.2 for formic acid in UBWOS 2013 are shown in Fig. S4. Besides the emission-based box model, a bimodal physical loss rate is applied to the simulation of the DSS method in UBWOS 2013 (Fig. 5). It is clear that the bimodal physical loss rate is able to simulate diurnal variations of formic acid better than constant physical loss rates.

In summary, the physical loss rate in the model does affect both the modeled absolute concentrations and the diurnal profile of formic acid significantly, as the chemical loss of formic acid is very slow. Physical loss rates in the box model not only influence formic acid, but also other secondary products (e.g., acetone; Fig. 5). We are able to obtain reasonable agreements between measurements and model results for formic acid in both magnitudes and diurnal profiles by "tuning" the physical loss rates in the box model during the two campaigns. However, simulation results for other compounds (e.g., acetone; Fig. 5) from the box model would then be much higher than the measurements. To account for the effects of physical loss processes, scatter plots of formic acid vs. acetone from box model simulations are shown in Fig. 6. Acetone is selected since (1) acetone was measured in both campaigns; (2) photochemical degradation of acetone, including reactions with $\mathrm{OH}$ radicals $\left(k_{\mathrm{OH}}=1.7 \times 10^{-13} \mathrm{~cm}^{3}\right.$ molecule ${ }^{-1} \mathrm{~s}^{-1}$ at $\left.298 \mathrm{~K}\right)$ Atkinson and Arey, 2003) and photolysis in MCM v3.2, is slow; (3) acetone can be modeled well using MCM (or other similar chemical mechanisms) for the UBWOS 2013 data (Edwards
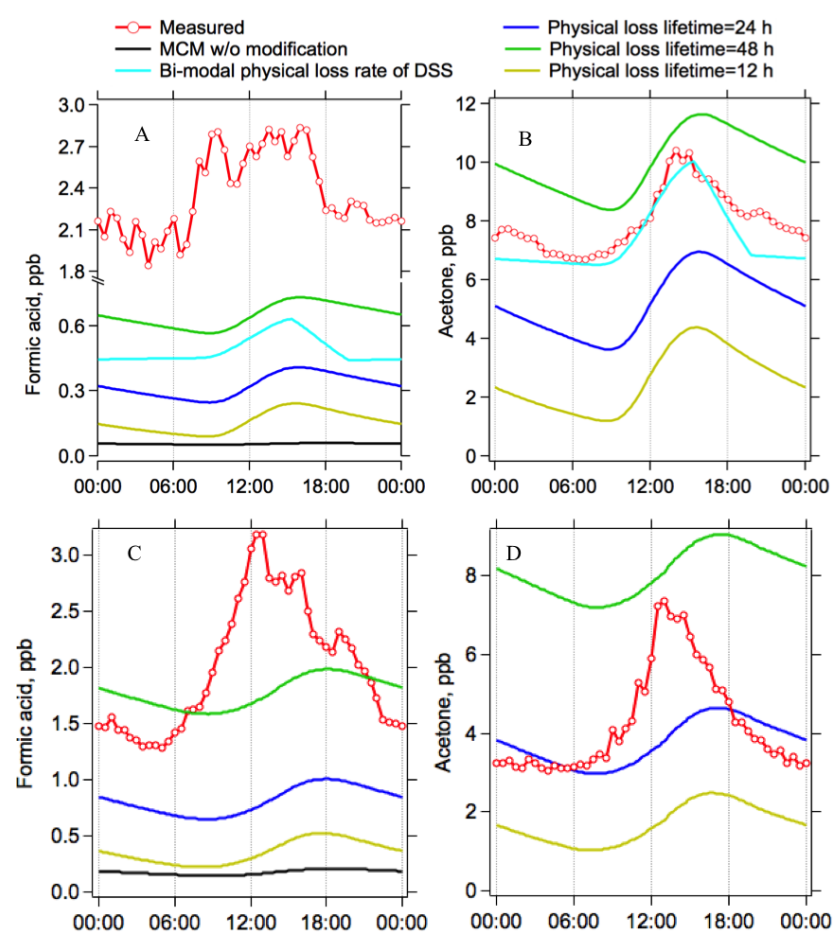

Figure 5. Comparison of measured and modeled diurnal profiles of formic acid and acetone for UBWOS $2013(\mathbf{a}, \mathbf{b})$ and CalNex (c, d) using different lifetimes due to physical losses.

et al., 2014) and in urban emission outflows (Sommariva et al., 2011; Apel et al., 2010). Good linear correlations between modeled formic acid and acetone are found for all tests of physical loss and the slopes are independent of the physical loss rates. The slopes in UBWOS 2013 and CalNex are 0.05 and $0.21 \mathrm{ppb} \mathrm{ppb}^{-1}$, respectively.

We acknowledge that the treatment of dilution and deposition in the box model by combining the two terms and assuming the same physical loss rate for different species may affect the modeled slopes of formic acid to acetone. (1) The background air that dilutes modeled air parcels in the box model contains no formic acid and acetone. A test simulation that assumes the modeled air parcel is diluted by background air with 0.1 of formic acid (Paulot et al., 2011) and $0.5 \mathrm{ppb}$ of acetone (Hu et al., 2013) for UBWOS 2013 is shown in Fig. S5. Very small changes of the simulated slope of formic acid vs. acetone are observed $(\sim 4 \%)$, compared with the simulation assuming background air without formic acid and acetone. (2) Deposition velocities for various species can be different. Based on the parameterization of deposition velocity (Wesely, 1989), the more soluble formic acid likely has a faster deposition rate than acetone. Accounting for this difference in deposition velocities, the modeled slope of formic acid vs. acetone would be even lower than those shown in Fig. 6.

Scatter plots of measured formic acid vs. acetone are compared with model results in Fig. 6, where diurnal aver- 

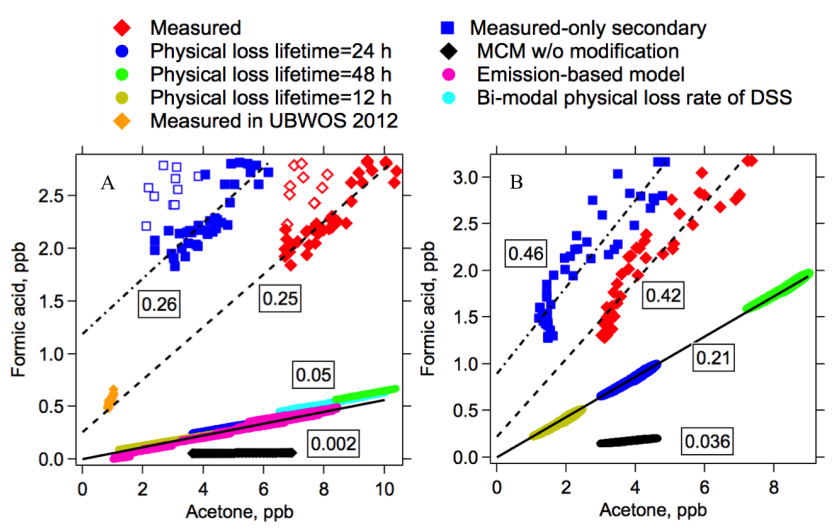

Figure 6. Scatter plots of formic acid vs. acetone in UBWOS 2013 (a) and CalNex (b). The measured values are $30 \mathrm{~min}$ diurnalaveraged data. The measured values in UBWOS 2012 are also shown in (a). The last-day diurnal results from the diurnal steady state (DSS) box model simulations are shown. Model results from the emission-based model and the DSS simulations using bimodal physical loss rates in UBWOS 2013 are also shown. Dashed and dash-dotted lines show fitted results from measured concentrations and estimated secondary concentrations, respectively. The fits in UBWOS 2013 exclude data in the 07:30-12:00 LT period (empty symbols, see text for details). Solid lines indicate the fitted results from model simulations with modified MCM in the two campaigns. Numbers in the graphs indicate enhancement ratios of formic acid to acetone from various data sets.

age data are shown. The measured enhancement ratios are $0.25 \mathrm{ppb} \mathrm{ppb}^{-1}$ in UBWOS 2013 and $0.42 \mathrm{ppb} \mathrm{ppb}^{-1}$ in CalNex, which are much larger than the modeled slopes. It should be noted that morning data points (07:30-12:00 LT) are excluded from the fit for UBWOS 2013 because the data at this time of day may have been influenced by fog events, which will be discussed in Sect. 3.5. Linear regressions using all ambient data points rather than diurnal averages produce only slightly different enhancement ratios (Fig. S6).

Using the measured and modeled enhancement ratios of formic acid to acetone (Fig. 6), we estimate that the modified MCM v3.2 can explain 20 and $50 \%$ of formic acid concentrations in UBWOS 2013 and CalNex, respectively. The box model simulations do not account for primary emissions for both formic acid and acetone; thus, concentrations due to secondary production for the two species are calculated by subtracting the primary concentrations (see discussions in Sect. 3.1) from the measured concentrations. This slightly changes the enhancement ratios in Fig. 6 and the explainable fractions of formic acid by modified MCM v3.2 change to 19 in UBWOS 2013 and $45 \%$ in CalNex, respectively. As emission compositions of hydrocarbons were not found to be different between UBWOS 2012 and UBWOS 2013, the performance of the emission-base box model can also represent the conditions in UBWOS 2012. As shown in Fig. 6, we observe a similar explainable fraction of formic acid in UBWOS 2012 as that in UBWOS 2013 by the box model.
Based on box model simulations with the modified MCM v3.2, the formation rates of formic acid are 3.2 in UBWOS 2013 and $8.2 \mathrm{ppbday}^{-1}$ in CalNex. We determine that additional formation rates of formic acid of 13.6 and $10.0 \mathrm{ppb} \mathrm{day}^{-1}$ are required to achieve agreement between box model simulations and measurements in UBWOS 2013 and CalNex, respectively. The additional formation rates of formic acid are equivalent to additional ethene concentrations of 30.3 in UBWOS 2013 and $19.1 \mathrm{ppb}$ in CalNex (daily average), which are 14.4 and 10.6 times the measured ethene concentrations in the two campaigns (UBWOS 2013: $2.1 \pm 0.2$; CalNex: $1.8 \pm 0.2 \mathrm{ppb}$ ). Alternatively, the additional formation rate of formic acid is equivalent to $1.3 \mathrm{ppb}$ of isoprene for the CalNex study, which is again much larger than the measured isoprene concentration $(0.33 \pm 0.32 \mathrm{ppb})$. Studies have shown that not all species are measured in the atmosphere by GC-MS, based on either $\mathrm{OH}$ reactivity measurements (Di Carlo et al., 2004) or more advanced measurement techniques (Lewis et al., 2000). However, the additional concentrations needed for alkenes to reproduce the observed formic acid concentrations are much larger than the fractions of potentially unmeasured species in the atmosphere.

We evaluated the chemical mechanisms of both alkenes and aromatics and included them in MCM v3.2. However, alkanes (including cycloalkanes), the most abundant compounds in UBWOS 2013 due to the emissions of oil and gas extraction (e.g., ethane: $305 \pm 30 \mathrm{ppb}$, propane: $141 \pm 14 \mathrm{ppb}$ ), are not included. Laboratory and field measurements showed that photooxidation of $>\mathrm{C} 5$ alkanes produces substituted dihydrofurans, which can react with ozone to form carboxylic acids (Zhang et al., 2014; Russell et al., 2011). However, it is unclear whether formic acid is produced. Assuming that alkanes were precursors of formic acid, yields of 6.9 and $21.3 \%$ from alkane oxidation could explain the missing formic acid source in UBWOS 2013 and CalNex, respectively. It is difficult to determine the relevance of the calculated yields to real atmospheric conditions due to lack of information. The calculated yields seem to be high compared with other compounds considered in this study (e.g., aromatics, $0-10 \%)$.

\subsection{Contributions from aqueous and heterogeneous reactions}

The box model simulations shown in Sect. 3.3 only account for formation pathways of formic acid in the gas phase. Previous studies showed that formic acid can also be formed from aqueous phase oxidation of formaldehyde (Chameides and Davis, 1983), glyoxal (Carlton et al., 2007), methylglyoxal (Tan et al., 2010) and glycolaldehyde (Perri et al., 2009). Formic acid formed in the aqueous phase can enter the gas phase through gas-particle partitioning or evaporation of water in cloud/aerosol. Formic acid can also be produced through heterogeneous reactions of aerosol with $\mathrm{OH}$ radi- 
cals (Vlasenko et al., 2008; Eliason et al., 2004) and ozone (Thomas et al., 2001; Dubowski et al., 2004).

The rate of aqueous reactions between $\mathrm{OH}$ radicals and dissolved organic carbon (DOC) can be expressed as

Rate $=k_{\mathrm{c}, \mathrm{OH}} \times[\mathrm{OH}] \times[\mathrm{DOC}]$,

where $k_{\mathrm{c}, \mathrm{OH}}$ is the rate constant for the reaction, and $[\mathrm{OH}]$ and [DOC] are the concentrations of $\mathrm{OH}$ radicals and DOC in the aqueous phase. The rate constant $k_{\mathrm{c}, \mathrm{OH}}$ is adopted as $3.8 \pm 1.9 \times 10^{8} \mathrm{~L}(\mathrm{~mol} \mathrm{C})^{-1} \mathrm{~s}^{-1}$ and $[\mathrm{OH}]$ is taken as $10^{-15}$ M for atmospheric particles (Arakaki et al., 2013). Measured OC in UBWOS 2013 and WSOC in CalNex are used as surrogates for DOC concentration in particles, respectively. Reaction rates are calculated to be $0.11 \pm 0.05 \mathrm{ppb} \mathrm{C} \mathrm{day}^{-1}$ for UBWOS 2013 and $0.06 \pm 0.04 \mathrm{ppb} \mathrm{C} \mathrm{day}^{-1}$ for CalNex. Assuming all of the carbon fluxes from DOC oxidation convert to formic acid and transfers to the gas phase, formation rates of formic acid from aqueous reactions are only $0.11 \pm 0.05$ for UBWOS 2013 and $0.06 \pm 0.04 \mathrm{ppb} d a y^{-1}$ for CalNex. It should be noted that formic acid is also consumed rapidly by $\mathrm{OH}$ radicals in the aqueous phase $\left(3 \times 10^{9} \mathrm{M}^{-1} \mathrm{~s}^{-1}\right)$ and formic acid $(\mathrm{pKa}=3.74$ at $298 \mathrm{~K})$ will only transfer efficiently to the gas phase when $\mathrm{pH}$ values in the aqueous phase are low. By comparing the formation rates from aqueous reactions and those needed to reproduce formic acid concentrations (Table 3), we conclude that aqueous reactions contribute little to formic acid concentration in both UBWOS $2013(0-0.7 \%)$ and CalNex (0-0.3\%).

The heterogeneous reaction rate (Rate) of oxidants on aerosol surface is determined from the collision flux of oxidants with aerosol and the uptake coefficient $(\gamma)$ :

Rate $=\frac{1}{4} \times v \times S \times\left[\mathrm{O}_{\mathrm{x}}\right] \times \gamma$,

where $v$ is the molecular velocity $\left(\mathrm{m} \mathrm{s}^{-1}\right)$, calculated as $(8 \mathrm{RT} / \pi \mathrm{M})^{0.5}$ ( $R$ is the universal gas constant, $T$ is the temperature, and $M$ is the molecular weight of the oxidant) (Kwan et al., 2006). $S$ is the ambient aerosol surface area $\left(\mathrm{cm}^{2} \mathrm{~cm}^{-3}\right)$. The dry surface area of aerosol is calculated from measurements of aerosol size distributions. Wet ambient aerosol surface area is determined by taking account for hygroscopic diameter growth, using the reported hygroscopicity parameter for CalNex $(\kappa=0.37)$ (Hersey et al., 2013) and a derived hygroscopicity parameter in UBWOS 2013 $(\kappa=0.31)$ based on the measured chemical compositions of aerosol. $\left[\mathrm{O}_{x}\right]$ is the oxidant concentration. Here we consider two different oxidants: $\mathrm{OH}$ radicals and ozone. The value of $\gamma$ for the $\mathrm{OH}$ radical is taken as unity (Bertram et al., 2001; Abbatt et al., 2012). The uptake coefficient $\gamma$ for ozone is estimated from the reported dependence of $\gamma$ on ozone concentrations (McCabe and Abbatt, 2008) $\left(4.1 \pm 0.5 \times 10^{-5}\right.$ in UBWOS 2013 and $1.1 \pm 0.5 \times 10^{-5}$ in CalNex). Here, diurnal averaged data for aerosol surface areas and concentrations of oxidant are used for the calculations. Heterogeneous reaction rates of $\mathrm{OH}$ radicals with aerosol are calculated to be 0.06 in UBWOS 2013 and $0.33 \mathrm{ppb} d a y^{-1}$ in CalNex, whereas reaction rates of ozone with aerosol are $12 \pm 2$ (UBWOS 2013) and $13 \pm 4 \mathrm{ppb}^{-1}{ }^{-1}$ (CalNex) (Table 3 ). If yields of formic acid from heterogeneous reactions (e.g., $<5 \%$ for alkenes with ozone (Thomas et al., 2001) are considered, formation rates of formic acid would then be less than $0.6 \pm 0.1$ in UBWOS 2013 and less than $0.7 \pm 0.2 \mathrm{ppb} \mathrm{day}^{-1}$ in CalNex. Thus, our best estimates for formation rates of formic acid from heterogeneous reactions should be $<1 \mathrm{ppb} d a y^{-1}$, which are not large contributions to the formic acid formation for either UBWOS $2013(0-6 \%)$ or CalNex (0-5\%). It should be noted that the calculations in the estimates of heterogeneous reactions are associated with large uncertainties, from both uptake coefficients and the yields of formic acid from the reactions. Future studies are warranted to provide better constraints on the contributions from heterogeneous reactions.

Besides aerosols, several morning fog events (e.g., on 2, 3 and 7 February) occurred during UBWOS 2013 that could potentially serve as reaction media for aqueous and heterogeneous reactions contributing to formic acid formation. Formic acid (measured as formate) has been identified as one of the main components of organic matter in fog droplets (Herckes et al., 2013). Figure 7 shows the time series of formic acid and other VOCs during a fog event on the morning of 7 February 2013. During this fog event, maximum concentrations of formic acid (up to $10.3 \mathrm{ppb}$ ) in UBWOS 2013 were recorded between 07:30 and 09:00 LT. Concentrations of other VOCs, including benzene, acetaldehyde, acetone and acetic acid, also increased during this period, indicating a more polluted air mass was encountered. However, enhancements in concentrations of both acetaldehyde and acetone were lower than those of formic acid (and acetic acid recorded by PTR-MS). Larger enhancements of formic acid relative to acetone during fog events on 2 and 3 February were also observed (not shown). It is also clear that formic acid and acetic acid decreased more than other VOCs in the early morning (06:00-07:30 LT). Time variations of formaldehyde are similar with two carboxylic acids, but different from acetaldehyde and acetone. This may reflect the dynamic absorption and release processes for these highly soluble species (formic acid, acetic acid and formaldehyde) to and from fog droplets in the fog event. Due to the lack of chemical measurements of fog water, we are not able to conclude whether formaldehyde contributes to formic acid enhancement during the fog events (Chameides and Davis, 1983; Keene et al., 1995). The different behaviors of formic acid and acetone in the fog events lead to deviation from the otherwise high correlations between the two compounds in the morning (Figs. 6, S6). Here, linear fit results from nonmorning data points in Fig. 6 are used to estimate formic acid concentration without the influence from fog events, and the difference between measured and estimated formic acid con- 
Table 3. Production rates of formic acid in the modified MCM v3.2 and the gaps between the box model simulations and measurements, and the reaction rates of aerosol-related reactions.

\begin{tabular}{lrr}
\hline Campaign & UBWOS 2013 & CalNex \\
\hline HCOOH production rate in modified MCM v3.2 $\left(\mathrm{ppb} \mathrm{day}^{-1}\right)$ & 3.2 & 8.2 \\
Additional $\mathrm{HCOOH}$ production rate needed $\left(\mathrm{ppb} \mathrm{day}^{-1}\right)$ & 13.6 & 10.0 \\
Additional $\mathrm{C}_{2} \mathrm{H}_{4}(\mathrm{ppb})$ & 30.3 & 19.1 \\
Additional $\mathrm{C}_{5} \mathrm{H}_{8}(\mathrm{ppb})$ & - & 1.3 \\
Yield of alkanes needed & $6.9 \%$ & $21.3 \%$ \\
DOC loss rate due to aqueous reactions $\left(\mathrm{ppb} \mathrm{C} \mathrm{day}^{-1}\right)$ & $0.11 \pm 0.05$ & $0.058 \pm 0.044$ \\
Reaction rate of $\mathrm{OH}$ with aerosol $\left(\mathrm{ppb} \mathrm{day}^{-1}\right)$ & 0.06 & 0.33 \\
Reactions rate of $\mathrm{O}_{3}$ with aerosol $\left(\mathrm{ppb} \mathrm{day}^{-1}\right)$ & $12 \pm 2$ & $13 \pm 4$ \\
\hline "-" indicates no calculation. & &
\end{tabular}

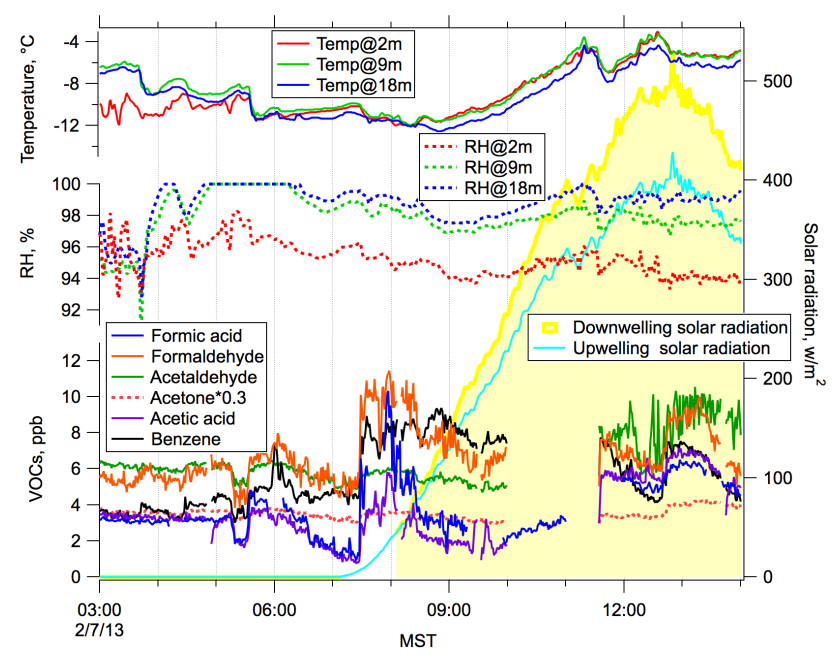

Figure 7. Time series of formic acid and other VOCs (benzene, acetone, formaldehyde, acetaldehyde and acetic acid) during the fog event on the morning of 7 February 2013 in UBWOS 2013. Measured ambient temperature and relative humidity $(\mathrm{RH})$ at different heights (2, 9 and $18 \mathrm{~m})$ and downwelling and upwelling solar radiation are also shown.

centrations in the morning can be attributed to fog events (Fig. S7). Using this approach, fog events in the morning in UBWOS 2013 are determined to enhance the campaignaveraged concentration of formic acid by $4 \pm 7 \%$. This contribution is not a large source for formic acid for the 4-week campaign, but fog formation accounted for significant formic acid concentrations in certain periods (e.g., the morning of 7 February).

\subsection{Contribution of air-snow exchange}

As mentioned earlier, the Uintah Basin was covered by snow during UBWOS 2013. The processes of air-snow exchange may provide another pathway for secondary formation of formic acid in the atmosphere (Jacobi et al., 2004; Dibb and Arsenault, 2002). Measured formic acid concentrations in pore spaces of the snowpacks (firn air) are much higher than in ambient air and formic acid may be formed from oxidation of carbonyls and alkenes within the snowpack (Dibb and Arsenault, 2002). During UBWOS 2013, sampling inlets of both NI-PT-CIMS and PTR-MS were mounted on a small tower that can move inlet heights between 1.0 and $7.5 \mathrm{~m}$. The inlet height was changed every $20 \mathrm{~min}$ from 7 to 16 February 2013 to obtain concentration gradients of formic acid, acetone, and other measured compounds.

Here, the concentration gradient is defined as the averaged concentration of each $20 \mathrm{~min}$ interval measured at $1.0 \mathrm{~m} \mathrm{mi-}$ nus the averaged concentration measured at $7.5 \mathrm{~m}$ in the preceding and subsequent cycles. Thus, positive (negative) vertical gradients indicate upward (downward) flux from (to) the snow surface. The calculated concentration gradients of formic acid and acetone are shown in Fig. 8. We did not observe a clear gradient direction for acetone during 7-16 February. The averaged concentration gradient observed during the time was $0.07 \pm 0.37 \mathrm{ppb}$ (average \pm standard deviation). However, two different periods showed strong gradients of formic acid: 7-12 February with a negative gradient $(-0.21 \pm 0.29 \mathrm{ppb})$ and $12-16$ February with a positive gradient $(0.22 \pm 0.25 \mathrm{ppb})$, both of the values are significantly different from zero $(p<0.01)$. Statistical tests also indicate that the gradient differences between the two periods are significant for formic acid $(p<0.01)$, but not for acetone. The different formic acid gradients in the two periods might be due to varying chemical compositions in the snow, possibly as the results of the snow event on 9 February. Unfortunately, formate data in the snow was not available during UBWOS 2013. Measured ions in the snow during UBWOS 2013 include oxalate and many other inorganic ions (e.g., nitrate). As the only measured organic ion in the snow, oxalate may be used as a proxy for formate, since formate and oxalate in the snow strongly correlate with each other (Norton, 1985). As shown in Fig. 8, neither time variations of oxalate in the snow nor nitric acid concentrations in ambient air correlated well with the concentration gradients of formic acid $(R=0.20$ and $R=0.21$, respectively), whereas the concentration prod- 

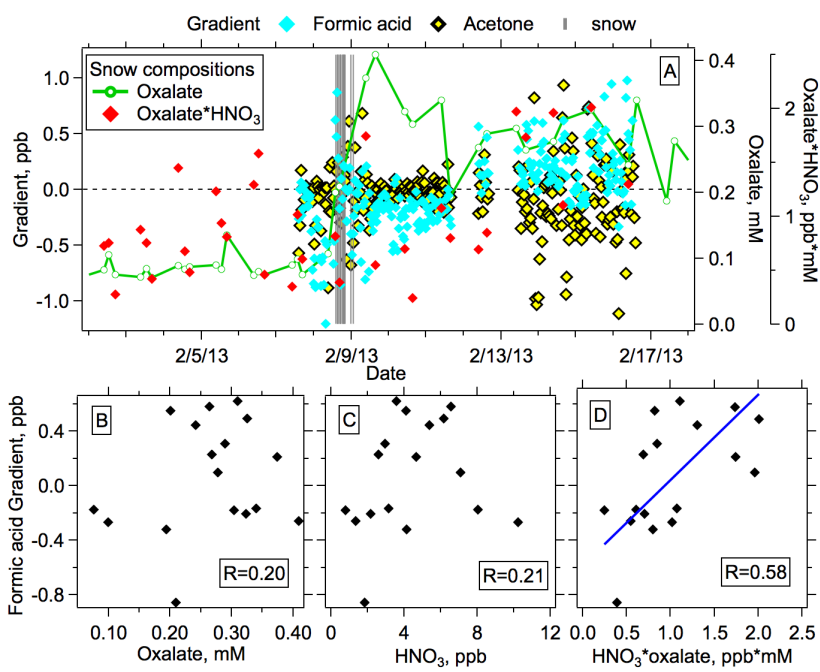

Figure 8. (a) Time series of concentration gradients of formic acid and acetone during UBWOS 2013. Time series of oxalate measured in melted snow water and the product of oxalate in the snow and nitric acid $\left(\mathrm{HNO}_{3}\right)$ in ambient air are also shown. The vertical black bars indicate periods with snowfall. (b) Scatter plot of concentration gradient of formic acid vs. oxalate in the snow. (c) Scatter plot of concentration gradient of formic acid vs. nitric acid concentration in ambient air. (d) Scatter plot of concentration gradients of formic acid vs. the products of oxalate in the snow and nitric acid in ambient air. The blue line is the linear regression to the data points.

ucts of oxalate in the snow and nitric acid in ambient air show a reasonable correlation with formic acid gradients $(R=0.58)$. This suggests that deposition of nitric acid to the snow surface and the acid displacement reactions due to nitric acid, which are thermodynamically favored $\left(\mathrm{HNO}_{3}+\right.$ $\left.\mathrm{HCOO}^{-}=\mathrm{NO}_{3}^{-}+\mathrm{HCOOH}, \Delta_{r} \mathrm{G}^{o}=-41 \mathrm{~kJ} \mathrm{~mol}^{-1}\right)($ Lide, 2005), may play important roles in the air-snow exchange of formic acid (and other organic acids). However, we cannot rule out other chemical processes and physical mechanisms that may account for air-snow exchange of formic acid in UBWOS 2013. Concurrent measurements of formate in snow, formic acid in ambient air and in firn air, and other chemical compositions in snow would be needed to answer this question.

Differences in vertical gradients for formic acid and acetone could be used to investigate the importance of air-snow exchange to formic acid concentrations in UBWOS 2013. The downward flux before 12 February and upward flux after 12 February of formic acid should cause different enhancement ratios of formic acid to acetone in the two periods. The measurements are in support of this statement (Fig. S8): enhancement ratios of $0.285 \mathrm{ppb} \mathrm{ppb}^{-1}$ before 12 February and $0.337 \mathrm{ppb} \mathrm{ppb}^{-1}$ after 12 February were observed. Thus, the difference in enhancement ratios between the two periods $(18 \pm 1 \%)$ can be considered an upper limit for the contribution of air-snow exchange to formic acid.

\subsection{Summary for both gas phase and non-gas phase processes}

Figure 9 shows the fractional contributions of various formation pathways to secondary formation of formic acid, including both gas phase reactions and other non-gas phase processes. Note that the upper limits of contributions from aerosol (aqueous reactions and heterogeneous reactions) are used in Fig. 9. Combining all of the processes and considering the lower and upper limits of contributions from aerosol-related reactions, current knowledge could explain 41-47 and $45-50 \%$ of the secondary formation of formic acid in UBWOS 2013 and CalNex, respectively. Inclusion of the non-gas phase processes helped narrow the gap of formic acid sources significantly, especially for UBWOS 2013 (from 81 to as low as $53 \%$ ). Even though the explained fractions of formic acid in UBWOS 2013 and CalNex are comparable, the processes producing formic acid are quite different. In CalNex, gas phase reactions (according to box model results) are much more important than aerosol-related production. This is in contrast to UBWOS 2013, where aerosol processes, air-snow exchange and fog events may account for significant contributions. In the gas phase, ozonolysis of alkenes, $\mathrm{OH}$ oxidation of isoprene $(13 \%)$ and $\mathrm{OH}$ oxidation of aromatics (12\%) are all important in CalNex, whereas $\mathrm{OH}$ oxidation of aromatics (12\%) dominates gas phase contribution to formic acid formation in UBWOS 2013.

Note that Fig. 9 should be viewed as the most "optimistic" case for formic acid formation in both UBWOS 2013 and CalNex. The upper limits are used to determine the fractions from many formation pathways in the production of formic acid, e.g., yields of formic acid from oxidation of aromatics. The newly proposed reaction with Criegee radicals may provide an additional sink of formic acid and the sink can reduce the modeled formic acid by $\sim 20 \%$ in the two campaigns, which is also not reflected in Fig. 9. Our treatment of deposition by assuming formic acid has the same deposition velocities as acetone may overestimate the modeled ratio of formic acid to acetone and, consequently, the percentages explained by the box model. One exception is that the formic acid yield from $\mathrm{OH}$ oxidation of isoprene used in this study is $20 \%$ lower than the literature value, which would only increase the fraction of isoprene reaction with $\mathrm{OH}$ radicals in Fig. 9 to $16 \%$ in CalNex. The reason for providing the most "optimistic" case in Fig. 9 is that many of the formation pathways included in the gas phase box model or non-gas phase processes are associated with large uncertainties. For example, all of the knowledge on vinyl alcohol oxidation producing formic acid comes from theoretical calculations without any evidence from direct measurements. Additional work on essentially all of the processes discussed in this study would be helpful to reduce the uncertainties in our understanding of secondary formic acid sources. In addition, half of observed secondary formations of formic acid are still unexplained in both campaigns; thus, explorations of new formation path- 


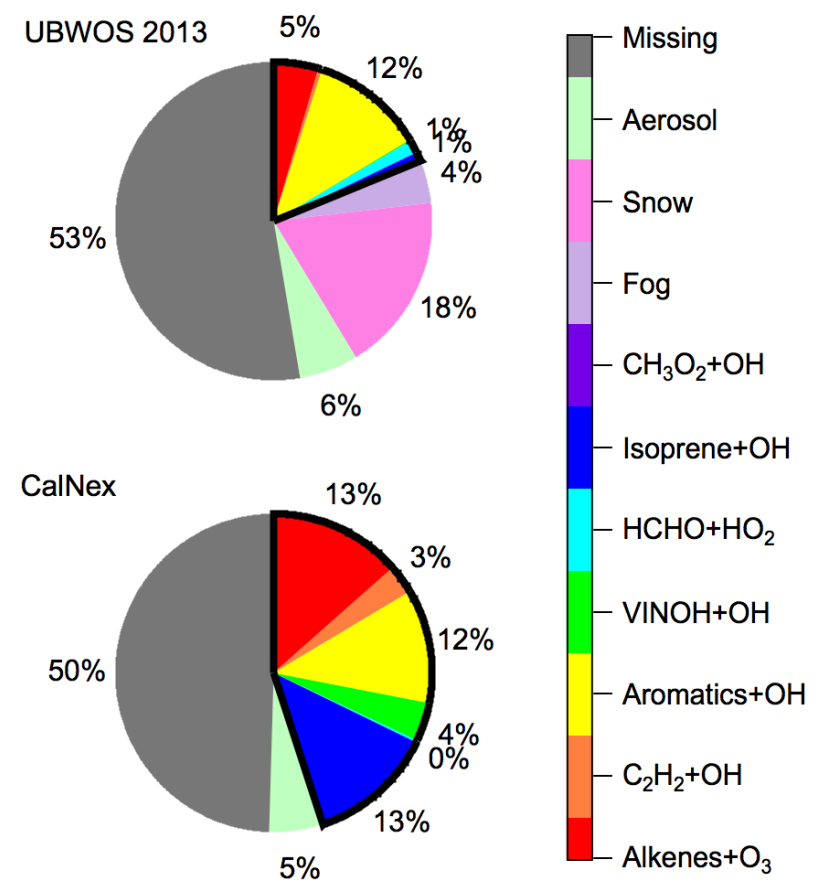

Figure 9. Contributions from various formation pathways to secondary production of formic acid in UBWOS 2013 (upper) and CalNex (bottom). Wedges with black outlines indicate the contributions from gas phase reactions.

ways for formic acid are needed to accurately reproduce the observed formic acid concentrations.

\section{Conclusions}

Formic acid was measured at an urban receptor site during CalNex and a site in an oil and gas producing region during UBWOS 2013. Secondary formation was the main source of formic acid during the two campaigns. Formic acid concentrations were comparable at both sites, even though the VOC compositions were very different from each other.

A box model is used to simulate secondary formation of formic acid for the two campaigns. The original chemical mechanisms derived from MCM v3.2 gave very large discrepancies between measured and modeled formic acid (lower by a factor of 40 in UBWOS 2013 and a factor of 13 in CalNex). Chemical mechanisms for formation pathways of formic acid reported in many recent studies are incorporated into MCM v3.2 for the box model, including updated yields of ozonolysis of alkenes, $\mathrm{OH}$ oxidation of isoprene, vinyl alcohol chemistry, reaction of formaldehyde with $\mathrm{HO}_{2}$, oxidation of aromatics and reaction of $\mathrm{CH}_{3} \mathrm{O}_{2}$ with $\mathrm{OH}$. The updated chemical mechanisms increase the modeled formic acid concentrations significantly, by a factor of 6.4 for the UBWOS 2013 case and a factor of 4.5 for the CalNex case. Based on correlations of formic acid with acetone from both measurement and model results, the influences from physical losses that are hard to represent in a box model are taken into account. We determine that the box model using an updated chemical mechanism can explain 19 and $45 \%$ of secondary formation of formic acid in UBWOS 2013 and CalNex, respectively.

Besides gas phase reactions, contributions from aerosolrelated reactions, fog events and air-snow exchange are also evaluated. Aerosol-related reactions (including aqueous and heterogeneous reactions) may account for $0-6$ and $0-5 \%$ of formic acid concentration in UBWOS 2013 and CalNex, respectively. Fog events and air-snow exchange in UBWOS 2013 contribute additional small fractions $(\sim 20 \%$ in total) to formic acid concentrations. Adding up all of the pathways, 41-47 and 45-50\% of secondary formation of formic acid can be explained in UBWOS 2013 and CalNex, respectively. However, the dominant formic acid sources in UBWOS 2013 and CalNex are completely different, which is a result of the different environments and atmospheric compositions for the two locations.

The Pasadena site investigated in this study during the summertime CalNex campaign is downwind of a major urban area. Considering the similar VOC compositions across different megacities (Borbon et al., 2013), secondary formation of formic acid in the urban plumes of other cities should demonstrate similar results to those shown in Fig. 9. Formic acid in urban plumes in winter may be more influenced by primary emissions, as discussed in a recent paper (Bannan et al., 2014). However, the wintertime UBWOS $2013 \mathrm{cam}$ paign at the Horse Pool site provides a good opportunity to investigate secondary formation of formic acid without either significant primary emissions or biogenic influence. The UBWOS 2013 case is unique since unconventional photochemistry at Horse Pool in winter helped to promote formation of secondary products (Edwards et al., 2014), including formic acid. Comparisons between the two different sites have helped to better understand secondary formation of formic acid. Nevertheless, more studies on formation pathways of formic acid, including those discussed in this study and new possible routes, are needed to narrow the gap between measurement and model results.

\section{The Supplement related to this article is available online at doi:10.5194/acp-15-1975-2015-supplement.}

Acknowledgements. This work was supported in part by the Western Energy Alliance. This work was also supported by the NOAA Health of the Atmosphere Program and by the NOAA Climate Program Office - Atmospheric Composition and Climate Program. We thank the contribution from Colm Sweeney (NOAA ESRL GMD) to methane data in UBWOS 2013. Bin Yuan acknowledges support from the National Research Council (NRC) Research Associateship Programs (RAP). Patrick Hayes and Jose-Luis 
Jimenez thank a CIRES Visiting Fellowship and funding from CARB (11-305) and NOAA NA13OAR4310063. Dylan Millet acknowledges support from NSF grant no. AGS-1148951.

Edited by: J. Collett

\section{References}

Abbatt, J. P. D., Lee, A. K. Y., and Thornton, J. A.: Quantifying trace gas uptake to tropospheric aerosol: recent advances and remaining challenges, Chem. Soc. Rev., 41, 6555-6581, 2012.

Akagi, S. K., Yokelson, R. J., Wiedinmyer, C., Alvarado, M. J., Reid, J. S., Karl, T., Crounse, J. D., and Wennberg, P. O.: Emission factors for open and domestic biomass burning for use in atmospheric models, Atmos. Chem. Phys., 11, 4039-4072, doi:10.5194/acp-11-4039-2011, 2011.

Alam, M. S., Camredon, M., Rickard, A. R., Carr, T., Wyche, K. P., Hornsby, K. E., Monks, P. S., and Bloss, W. J.: Total radical yields from tropospheric ethene ozonolysis, Phys. Chem. Chem. Phys., 13, 11002-11015, doi:10.1039/c0cp02342f, 2011.

Andrews, D. U., Heazlewood, B. R., Maccarone, A. T., Conroy, T., Payne, R. J., Jordan, M. J. T., and Kable, S. H.: Phototautomerization of Acetaldehyde to Vinyl Alcohol: A Potential Route to Tropospheric Acids, Science, 337, 1203-1206, doi:10.1126/science.1220712, 2012.

Apel, E. C., Emmons, L. K., Karl, T., Flocke, F., Hills, A. J., Madronich, S., Lee-Taylor, J., Fried, A., Weibring, P., Walega, J., Richter, D., Tie, X., Mauldin, L., Campos, T., Weinheimer, A., Knapp, D., Sive, B., Kleinman, L., Springston, S., Zaveri, R., Ortega, J., Voss, P., Blake, D., Baker, A., Warneke, C., Welsh-Bon, D., de Gouw, J., Zheng, J., Zhang, R., Rudolph, J., Junkermann, W., and Riemer, D. D.: Chemical evolution of volatile organic compounds in the outflow of the Mexico City Metropolitan area, Atmos. Chem. Phys., 10, 2353-2375, doi:10.5194/acp-10-23532010, 2010.

Arakaki, T., Anastasio, C., Kuroki, Y., Nakajima, H., Okada, K., Kotani, Y., Handa, D., Azechi, S., Kimura, T., Tsuhako, A., and Miyagi, Y.: A General Scavenging Rate Constant for Reaction of Hydroxyl Radical with Organic Carbon in Atmospheric Waters, Envir. Sci. Tech. Lib., 47, 8196-8203, doi:10.1021/es401927b, 2013.

Archibald, A. T., McGillen, M. R., Taatjes, C. A., Percival, C. J., and Shallcross, D. E.: Atmospheric transformation of enols: A potential secondary source of carboxylic acids in the urban troposphere, Geophys. Res. Lett., 34, L21801, doi:10.1029/2007g1031032, 2007.

Archibald, A. T., Petit, A. S., Percival, C. J., Harvey, J. N., and Shallcross, D. E.: On the importance of the reaction between $\mathrm{OH}$ and $\mathrm{RO}_{2}$ radicals, Atmos. Sci. Lett., 10, 102-108, doi:10.1002/as1.216, 2009.

Atkinson, R. and Arey, J.: Atmospheric degradation of volatile organic compounds, Chem. Rev., 103, 4605-4638, doi:10.1021/Cr0206420, 2003.

Atkinson, R., Baulch, D. L., Cox, R. A., Crowley, J. N., Hampson, R. F., Hynes, R. G., Jenkin, M. E., Rossi, M. J., Troe, J., and IUPAC Subcommittee: Evaluated kinetic and photochemical data for atmospheric chemistry: Volume II - gas phase re- actions of organic species, Atmos. Chem. Phys., 6, 3625-4055, doi:10.5194/acp-6-3625-2006, 2006.

Baltensperger, U., Kalberer, M., Dommen, J., Paulsen, D., Alfarra, M., Coe, H., Fisseha, R., Gascho, A., Gysel, M., and Nyeki, S.: Secondary organic aerosols from anthropogenic and biogenic precursors, Faraday Discuss, 130, 265-278, 2005.

Bannan, T. J., Bacak, A., Muller, J. B. A., Booth, A. M., Jones, B., Le Breton, M., Leather, K. E., Ghalaieny, M., Xiao, P., Shallcross, D. E., and Percival, C. J.: Importance of direct anthropogenic emissions of formic acid measured by a chemical ionisation mass spectrometer (CIMS) during the Winter ClearfLo Campaign in London, January 2012, Atmos. Environ., 83, 301310, doi:10.1016/J.Atmosenv.2013.10.029, 2014.

Bates, K. H., Crounse, J. D., St. Clair, J. M., Bennett, N. B., Nguyen, T. B., Seinfeld, J. H., Stoltz, B. M., and Wennberg, P. O.: Gas Phase Production and Loss of Isoprene Epoxydiols, J. Phys. Chem. A, 118, 1237-1246, doi:10.1021/jp4107958, 2014.

Berndt, T. and Böge, O.: Gas-phase reaction of $\mathrm{OH}$ radicals with benzene: products and mechanism, Phys. Chem. Chem. Phys., 3, 4946-4956, doi:10.1039/b106667f, 2001.

Berndt, T., Böge, O., and Herrmann, H.: On the formation of benzene oxide/oxepin in the gas-phase reaction of $\mathrm{OH}$ radicals with benzene, Chem. Phys. Lett., 314, 435-442, doi:10.1016/S00092614(99)01041-6, 1999.

Bertram, A. K., Ivanov, A. V., Hunter, M., Molina, L. T., and Molina, M. J.: The Reaction Probability of $\mathrm{OH}$ on Organic Surfaces of Tropospheric Interest, J. Phys. Chem. A, 105, 94159421, doi:10.1021/jp0114034, 2001.

Bon, D. M., Ulbrich, I. M., de Gouw, J. A., Warneke, C., Kuster, W. C., Alexander, M. L., Baker, A., Beyersdorf, A. J., Blake, D., Fall, R., Jimenez, J. L., Herndon, S. C., Huey, L. G., Knighton, W. B., Ortega, J., Springston, S., and Vargas, O.: Measurements of volatile organic compounds at a suburban ground site (T1) in Mexico City during the MILAGRO 2006 campaign: measurement comparison, emission ratios, and source attribution, Atmos. Chem. Phys., 11, 2399-2421, doi:10.5194/acp-11-23992011, 2011.

Borbon, A., Gilman, J. B., Kuster, W. C., Grand, N., Chevaillier, S., Colomb, A., Dolgorouky, C., Gros, V., Lopez, M., Sarda-Esteve, R., Holloway, J., Stutz, J., Petetin, H., McKeen, S., Beekmann, M., Warneke, C., Parrish, D. D., and de Gouw, J. A.: Emission ratios of anthropogenic volatile organic compounds in northern mid-latitude megacities: Observations vs. emission inventories in Los Angeles and Paris, J. Geophys. Res.-Atmos., 118, 1-17, doi:10.1002/jgrd.50059, 2013.

Bossolasco, A., Faragó, E. P., Schoemaecker, C., and Fittschen, C.: Rate constant of the reaction between $\mathrm{CH}_{3} \mathrm{O}_{2}$ and $\mathrm{OH}$ radicals, Chem. Phys. Lett., 593, 7-13, doi:10.1016/j.cplett.2013.12.052, 2014.

Butkovskaya, N. I., Pouvesle, N., Kukui, A., and Le Bras, G.: Mechanism of the $\mathrm{OH}$-Initiated Oxidation of Glycolaldehyde over the Temperature Range 233-296, J. Phys. Chem. A, 110, 1349213499, doi:10.1021/jp064993k, 2006a.

Butkovskaya, N. I., Pouvesle, N., Kukui, A., Mu, Y., and Le Bras, G.: Mechanism of the OH-Initiated Oxidation of Hydroxyacetone over the Temperature Range 236-298 K, J. Phys. Chem. A, 110, 6833-6843, doi:10.1021/jp056345r, 2006b.

Cady-Pereira, K. E., Chaliyakunnel, S., Shephard, M. W., Millet, D. B., Luo, M., and Wells, K. C.: HCOOH measurements 
from space: TES retrieval algorithm and observed global distribution, Atmos. Meas. Tech., 7, 2297-2311, doi:10.5194/amt-72297-2014, 2014.

Carlton, A. G., Turpin, B. J., Lim, H. J., Altieri, K. E., and Seitzinger, S.: Link between isoprene and secondary organic aerosol (SOA): Pyruvic acid oxidation yields low volatility organic acids in clouds, Geophys. Res. Lett., 33, L06822, doi:10.1029/2005g1025374, 2006.

Carlton, A. G., Turpin, B. J., Altieri, K. E., Seitzinger, S., Reff, A., Lim, H.-J., and Ervens, B.: Atmospheric oxalic acid and SOA production from glyoxal: Results of aqueous photooxidation experiments, Atmos. Environ., 41, 7588-7602, doi:10.1016/j.atmosenv.2007.05.035, 2007.

Chameides, W. L. and Davis, D. D.: Aqueous-phase source of formic acid in clouds, Nature, 304, 427-429, 1983.

Chebbi, A. and Carlier, P.: Carboxylic acids in the troposphere, occurrence, sources, and sinks: A review, Atmos. Environ., 30, 4233-4249, 1996.

Crisp, T. A., Brady, J. M., Cappa, C. D., Collier, S., Forestieri, S. D., Kleeman, M. J., Kuwayama, T., Lerner, B. M., Williams, E. J., Zhang, Q., and Bertram, T. H.: On the primary emission of formic acid from light duty gasoline vehicles and ocean-going vessels, Atmos. Environ., 98, 426-433, doi:10.1016/j.atmosenv.2014.08.070, 2014.

da Silva, G.: Carboxylic Acid Catalyzed Keto-Enol Tautomerizations in the Gas Phase, Ange. Chem. Int. Edit., 49, 7523-7525, doi:10.1002/anie.201003530, 2010.

Daele, V. and Poulet, G.: Kinetics and products of the reactions of $\mathrm{CH}_{3} \mathrm{O}_{2}$ with $\mathrm{Cl}$ and $\mathrm{ClO}$, J. Chim. Phys. Pcb., 93, 1081-1099, 1996.

de Gouw, J. A., Middlebrook, A. M., Warneke, C., Goldan, P. D., Kuster, W. C., Roberts, J. M., Fehsenfeld, F. C., Worsnop, D. R., Canagaratna, M. R., Pszenny, A. A. P., Keene, W. C., Marchewka, M., Bertman, S. B., and Bates, T. S.: Budget of organic carbon in a polluted atmosphere: Results from the New England Air Quality Study in 2002, J. Geophys. Res.-Atmos., 110, D16305, doi:10.1029/2004jd005623, 2005.

Di Carlo, P., Brune, W. H., Martinez, M., Harder, H., Lesher, R., Ren, X., Thornberry, T., Carroll, M. A., Young, V., Shepson, P. B., Riemer, D., Apel, E., and Campbell, C.: Missing OH Reactivity in a Forest: Evidence for Unknown Reactive Biogenic VOCs, Science, 304, 722-725, doi:10.1126/science.1094392, 2004.

Dibb, J. E. and Arsenault, M.: Shouldn't snowpacks be sources of monocarboxylic acids?, Atmos. Environ., 36, 2513-2522, doi:10.1016/S1352-2310(02)00131-0, 2002.

Dubé, W. P., Brown, S. S., Osthoff, H. D., Nunley, M. R., Ciciora, S. J., Paris, M. W., McLaughlin, R. J., and Ravishankara, A. R.: Aircraft instrument for simultaneous, in situ measurement of $\mathrm{NO}_{3}$ and $\mathrm{N}_{2} \mathrm{O} 5$ via pulsed cavity ring-down spectroscopy, Rev. Sci. Instrum., 77, 034101, doi:10.1063/1.2176058, 2006.

Dubowski, Y., Vieceli, J., Tobias, D. J., Gomez, A., Lin, A., Nizkorodov, S. A., McIntire, T. M., and Finlayson-Pitts, B. J.: Interaction of Gas-Phase Ozone at $296 \mathrm{~K}$ with Unsaturated SelfAssembled Monolayers:? A New Look at an Old System, J. Phys. Chem. A, 108, 10473-10485, doi:10.1021/jp046604x, 2004.

Edwards, P. M., Young, C. J., Aikin, K., deGouw, J., Dubé, W. P., Geiger, F., Gilman, J., Helmig, D., Holloway, J. S., Kercher, J., Lerner, B., Martin, R., McLaren, R., Parrish, D. D., Peischl, J., Roberts, J. M., Ryerson, T. B., Thornton, J., Warneke, C.,
Williams, E. J., and Brown, S. S.: Ozone photochemistry in an oil and natural gas extraction region during winter: simulations of a snow-free season in the Uintah Basin, Utah, Atmos. Chem. Phys., 13, 8955-8971, doi:10.5194/acp-13-8955-2013, 2013.

Edwards, P. M., Brown, S. S., Roberts, J. M., Ahmadov, R., Banta, R. M., deGouw, J. A., Dube, W. P., Field, R. A., Flynn, J. H., Gilman, J. B., Graus, M., Helmig, D., Koss, A., Langford, A. O., Lefer, B. L., Lerner, B. M., Li, R., Li, S. M., McKeen, S. A., Murphy, S. M., Parrish, D. D., Senff, C. J., Soltis, J., Stutz, J., Sweeney, C., Thompson, C. R., Trainer, M. K., Tsai, C., Veres, P. R., Washenfelder, R. A., Warneke, C., Wild, R. J., Young, C. J., Yuan, B., and Zamora, R.: High winter ozone pollution from carbonyl photolysis in an oil and gas basin, Nature, 514, 351354, doi:10.1038/nature13767, 2014.

Eliason, T. L., Gilman, J. B., and Vaida, V.: Oxidation of organic films relevant to atmospheric aerosols, Atmos. Environ., 38, 1367-1378, doi:10.1016/j.atmosenv.2003.11.025, 2004.

Emmerson, K. M. and Evans, M. J.: Comparison of tropospheric gas-phase chemistry schemes for use within global models, Atmos. Chem. Phys., 9, 1831-1845, doi:10.5194/acp-9-1831-2009, 2009.

Fittschen, C., Whalley, L. K., and Heard, D. E.: The reaction of $\mathrm{CH}_{3} \mathrm{O}_{2}$ radicals with $\mathrm{OH}$ radicals: a neglected sink for $\mathrm{CH}_{3} \mathrm{O}_{2}$ in the remote atmosphere, Environ. Sci. Technol., 48, 7700-7701, doi:10.1021/es502481q, 2014.

Fried, A., Crawford, J., Olson, J., Walega, J., Potter, W., Wert, B., Jordan, C., Anderson, B., Shetter, R., Lefer, B., Blake, D., Blake, N., Meinardi, S., Heikes, B., O’Sullivan, D., Snow, J., Fuelberg, H., Kiley, C. M., Sandholm, S., Tan, D., Sachse, G., Singh, H., Faloona, I., Harward, C. N., and Carmichael, G. R.: Airborne tunable diode laser measurements of formaldehyde during TRACEP: Distributions and box model comparisons, J. Geophys. Res.Atmos., 108, 8798, doi:10.1029/2003jd003451, 2003.

Fried, A., Walega, J. G., Olson, J. R., Crawford, J. H., Chen, G., Weibring, P., Richter, D., Roller, C., Tittel, F. K., Heikes, B. G., Snow, J. A., Shen, H., O’Sullivan, D. W., Porter, M., Fuelberg, H., Halland, J., and Millet, D. B.: Formaldehyde over North America and the North Atlantic during the summer 2004 INTEX campaign: Methods, observed distributions, and measurement-model comparisons, J. Geophys. Res., 113, D10302, doi:10.1029/2007jd009185, 2008.

Gilman, J. B., Lerner, B. M., Kuster, W. C., and de Gouw, J. A.: Source signature of volatile organic compounds from oil and natural gas operations in northeastern Colorado, Environ. Sci. Technol., 47, 1297-1305, doi:10.1021/es304119a, 2013.

Grosjean, D., Williams, E. L., and Grosjean, E.: Atmospheric Chemistry of Isoprene and of Its Carbonyl Products, Environ. Sci. Technol., 27, 830-840, 1993.

Hatakeyama, S., Washida, N., and Akimoto, H.: Rate constants and mechanisms for the reaction of hydroxyl (OD) radicals with acetylene, propyne, and 2-butyne in air at $297 \pm 2 \mathrm{~K}$, J. Phys. Chem., 90, 173-178, doi:10.1021/j100273a039, 1986.

Helmig, D., Thompson, C. R., Evans, J., Boylan, P., Hueber, J., and Park, J. H.: Highly elevated atmospheric levels of volatile organic compounds in the Uintah Basin, Utah, Environ. Sci. Technol., 48, 4707-4715, doi:10.1021/es405046r, 2014.

Herckes, P., Valsaraj, K. T., and Collett Jr, J. L.: A review of observations of organic matter in fogs and clouds: Ori- 
gin, processing and fate, Atmos. Res., 132-133, 434-449, doi:10.1016/j.atmosres.2013.06.005, 2013.

Hersey, S. P., Craven, J. S., Metcalf, A. R., Lin, J., Lathem, T., Suski, K. J., Cahill, J. F., Duong, H. T., Sorooshian, A., Jonsson, H. H., Shiraiwa, M., Zuend, A., Nenes, A., Prather, K. A., Flagan, R. C., and Seinfeld, J. H.: Composition and hygroscopicity of the Los Angeles Aerosol: CalNex, J. Geophys. Res.-Atmos., 118, 30163036, doi:10.1002/jgrd.50307, 2013.

Hu, L., Millet, D. B., Kim, S. Y., Wells, K. C., Griffis, T. J., Fischer, E. V., Helmig, D., Hueber, J., and Curtis, A. J.: North American acetone sources determined from tall tower measurements and inverse modeling, Atmos. Chem. Phys., 13, 33793392, doi:10.5194/acp-13-3379-2013, 2013.

Ito, A., Sillman, S., and Penner, J. E.: Effects of additional nonmethane volatile organic compounds, organic nitrates, and direct emissions of oxygenated organic species on global tropospheric chemistry, J. Geophys. Res.-Atmos., 112, D06309, doi:10.1029/2005jd006556, 2007.

Jacobi, H.-W., Bales, R. C., Honrath, R. E., Peterson, M. C., Dibb, J. E., Swanson, A. L., and Albert, M. R.: Reactive trace gases measured in the interstitial air of surface snow at Summit, Greenland, Atmos. Environ., 38, 1687-1697, doi:10.1016/j.atmosenv.2004.01.004, 2004.

Jardine, K., Yañez Serrano, A., Arneth, A., Abrell, L., Jardine, A., Artaxo, P., Alves, E., Kesselmeier, J., Taylor, T., Saleska, S., and Huxman, T.: Ecosystem-scale compensation points of formic and acetic acid in the central Amazon, Biogeosciences, 8, 37093720, doi:10.5194/bg-8-3709-2011, 2011.

Jenkin, M. E., Hurley, M. D., and Wallington, T. J.: Investigation of the radical product channel of the $\mathrm{CH}_{3} \mathrm{C}(\mathrm{O}) \mathrm{O}_{2}+\mathrm{HO}_{2}$ reaction in the gas phase, Phys. Chem. Chem. Phys., 9, 3149-3162, doi:10.1039/b702757e, 2007.

Jenkin, M. E., Wyche, K. P., Evans, C. J., Carr, T., Monks, P. S., Alfarra, M. R., Barley, M. H., McFiggans, G. B., Young, J. C., and Rickard, A. R.: Development and chamber evaluation of the MCM v3.2 degradation scheme for $\beta$-caryophyllene, Atmos. Chem. Phys., 12, 5275-5308, doi:10.5194/acp-12-52752012, 2012.

Karton, A.: Inorganic acid-catalyzed tautomerization of vinyl alcohol to acetaldehyde, Chem. Phys. Lett., 592, 330-333, doi:10.1016/j.cplett.2013.12.062, 2014.

Kawamura, K., Steinberg, S., and Kaplan, I. R.: Homologous series of C1-C10 monocarboxylic acids and C1-C6 carbonyls in Los Angeles air and motor vehicle exhausts, Atmos. Environ., 34, 4175-4191, 2000.

Keene, W. C., Mosher, B. W., Jacob, D. J., Munger, J. W., Talbot, R. W., Artz, R. S., Maben, J. R., Daube, B. C., and Galloway, J. N.: Carboxylic acids in clouds at a high-elevation forested site in central Virginia, J. Geophys. Res.-Atmos., 100, 9345-9357, doi:10.1029/94JD01247, 1995

Khare, P., Kumar, N., Kumari, K. M., and Srivastava, S. S.: Atmospheric formic and acetic acids: An overview, Rev. Geophys., 37, 227-248, 1999.

Kwan, A. J., Crounse, J. D., Clarke, A. D., Shinozuka, Y., Anderson, B. E., Crawford, J. H., Avery, M. A., McNaughton, C. S., Brune, W. H., Singh, H. B., and Wennberg, P. O.: On the flux of oxygenated volatile organic compounds from organic aerosol oxidation, Geophys. Res. Lett., 33, L15815, doi:10.1029/2006GL026144, 2006.
Le Breton, M., McGillen, M. R., Muller, J. B. A., Bacak, A., Shallcross, D. E., Xiao, P., Huey, L. G., Tanner, D., Coe, H., and Percival, C. J.: Airborne observations of formic acid using a chemical ionization mass spectrometer, Atmos. Meas. Tech., 5, 30293039, doi:10.5194/amt-5-3029-2012, 2012.

Le Breton, M., Bacak, A., Muller, J. B. A., Xiao, P., Shallcross, B. M. A., Batt, R., Cooke, M. C., Shallcross, D. E., Bauguitte, S. J. B., and Percival, C. J.: Simultaneous airborne nitric acid and formic acid measurements using a chemical ionization mass spectrometer around the UK: Analysis of primary and secondary production pathways, Atmos. Environ., 83, 166-175, doi:10.1016/j.atmosenv.2013.10.008, 2014.

Leather, K. E., McGillen, M. R., Cooke, M. C., Utembe, S. R., Archibald, A. T., Jenkin, M. E., Derwent, R. G., Shallcross, D. E., and Percival, C. J.: Acid-yield measurements of the gas-phase ozonolysis of ethene as a function of humidity using Chemical Ionisation Mass Spectrometry (CIMS), Atmos. Chem. Phys., 12, 469-479, doi:10.5194/acp-12-469-2012, 2012.

Lee, A., Goldstein, A. H., Keywood, M. D., Gao, S., Varutbangkul, V., Bahreini, R., Ng, N. L., Flagan, R. C., and Seinfeld, J. H.: Gas-phase products and secondary aerosol yields from the ozonolysis of ten different terpenes, J. Geophys. Res.-Atmos., 111, D07302, doi:10.1029/2005jd006437, 2006.

Lewis, A. C., Carslaw, N., Marriott, P. J., Kinghorn, R. M., Morrison, P., Lee, A. L., Bartle, K. D., and Pilling, M. J.: A larger pool of ozone-forming carbon compounds in urban atmospheres, Nature, 405, 778-781, 2000.

Li, X., Rohrer, F., Brauers, T., Hofzumahaus, A., Lu, K., Shao, M., Zhang, Y. H., and Wahner, A.: Modeling of HCHO and CHO$\mathrm{CHO}$ at a semi-rural site in southern China during the PRIDEPRD2006 campaign, Atmos. Chem. Phys., 14, 12291-12305, doi:10.5194/acp-14-12291-2014, 2014.

Lide, D. R.: CRC Handbook of Chemistry and Physics, avialable at: http://www.hbcpnetbase.com, 2005

Liu, J., Zhang, X., Parker, E. T., Veres, P. R., Roberts, J. M., de Gouw, J. A., Hayes, P. L., Jimenez, J. L., Murphy, J. G., Ellis, R. A., Huey, L. G., and Weber, R. J.: On the gas-particle partitioning of soluble organic aerosol in two urban atmospheres with contrasting emissions: 2. Gas and particle phase formic acid, J. Geophys. Res., 117, D00V21, doi:10.1029/2012jd017912, 2012.

Maricq, M. M., Szente, J. J., Kaiser, E. W., and Shi, J.: Reaction of Chlorine Atoms with Methylperoxy and Ethylperoxy Radicals, J. Phys. Chem., 98, 2083-2089, doi:10.1021/j100059a017, 1994.

McCabe, J. and Abbatt, J. P. D.: Heterogeneous Loss of Gas-Phase Ozone on $n$-Hexane Soot Surfaces: Similar Kinetics to Loss on Other Chemically Unsaturated Solid Surfaces, J. Phys. Chem. C, 113, 2120-2127, doi:10.1021/jp806771q, 2008.

Molina, M. J., Ivanov, A. V., Trakhtenberg, S., and Molina, L. T.: Atmospheric evolution of organic aerosol, Geophys. Res. Lett. 31, L22104, doi:10.1029/2004g1020910, 2004.

Muller, J. F. and Peeters, J.: Interactive comment on " $\mathrm{HCOOH}$ measurements from space: TES retrieval algorithm and observed global distribution" by K. E. Cady-Pereira et al., Atmos. Meas. Tech. Discuss., 7, C312-C314, 2014.

Neeb, P., Sauer, F., Horie, O., and Moortgat, G. K.: Formation of hydroxymethyl hydroperoxide and formic acid in alkene ozonolysis in the presence of water vapour, Atmos. Environ., 31, 1417 1423, doi:10.1016/S1352-2310(96)00322-6, 1997. 
Norton, R. B.: Measurements of formate and acetate in precipitation at Niwot Ridge and Boulder, Colorado, Geophys. Res. Lett., 12, 769-772, doi:10.1029/GL012i011p00769, 1985.

Orlando, J. J., Nozière, B., Tyndall, G. S., Orzechowska, G. E., Paulson, S. E., and Rudich, Y.: Product studies of the OH- and ozone-initiated oxidation of some monoterpenes, J. Geophys. Res.-Atmos., 105, 11561-11572, doi:10.1029/2000jd900005, 2000.

Orlando, J., Tyndall, G., and Taraborrelli, D.: Atmospheric Oxidation of Two Isoprene By-Products, Hydroxyacetone and Glycolaldehyde, AGU Fall Meeting 2012, San Francisco, 3-7 December, 2012.

Paulot, F., Crounse, J. D., Kjaergaard, H. G., Kroll, J. H., Seinfeld, J. H., and Wennberg, P. O.: Isoprene photooxidation: new insights into the production of acids and organic nitrates, Atmos. Chem. Phys., 9, 1479-1501, doi:10.5194/acp-9-1479-2009, 2009a.

Paulot, F., Crounse, J. D., Kjaergaard, H. G., Kurten, A., St Clair, J. M., Seinfeld, J. H., and Wennberg, P. O.: Unexpected Epoxide Formation in the Gas-Phase Photooxidation of Isoprene, Science, 325, 730-733, doi:10.1126/science.1172910, 2009b.

Paulot, F., Wunch, D., Crounse, J. D., Toon, G. C., Millet, D. B., DeCarlo, P. F., Vigouroux, C., Deutscher, N. M., González Abad, G., Notholt, J., Warneke, T., Hannigan, J. W., Warneke, C., de Gouw, J. A., Dunlea, E. J., De Mazière, M., Griffith, D. W. T., Bernath, P., Jimenez, J. L., and Wennberg, P. O.: Importance of secondary sources in the atmospheric budgets of formic and acetic acids, Atmos. Chem. Phys., 11, 1989-2013, doi:10.5194/acp-11-1989-2011, 2011.

Perri, M. J., Seitzinger, S., and Turpin, B. J.: Secondary organic aerosol production from aqueous photooxidation of glycolaldehyde: Laboratory experiments, Atmos. Environ., 43, 1487-1497, doi:10.1016/j.atmosenv.2008.11.037, 2009.

Russell, L. M., Bahadur, R., and Ziemann, P. J.: Identifying organic aerosol sources by comparing functional group composition in chamber and atmospheric particles, P. Natl. Acad. Sci. USA, 108, 3516-3521, doi:10.1073/pnas.1006461108, 2011.

Ryerson, T. B., Andrews, A. E., Angevine, W. M., Bates, T. S., Brock, C. A., Cairns, B., Cohen, R. C., Cooper, O. R., de Gouw, J. A., Fehsenfeld, F. C., Ferrare, R. A., Fischer, M. L., Flagan, R. C., Goldstein, A. H., Hair, J. W., Hardesty, R. M., Hostetler, C. A., Jimenez, J. L., Langford, A. O., McCauley, E., McKeen, S. A., Molina, L. T., Nenes, A., Oltmans, S. J., Parrish, D. D., Pederson, J. R., Pierce, R. B., Prather, K., Quinn, P. K., Seinfeld, J. H., Senff, C. J., Sorooshian, A., Stutz, J., Surratt, J. D., Trainer, M., Volkamer, R., Williams, E. J., and Wofsy, S. C.: The 2010 California Research at the Nexus of Air Quality and Climate Change (CalNex) field study, J. Geophys. Res.-Atmos., 118, 5830-5866, doi:10.1002/jgrd.50331, 2013.

Saunders, S. M., Jenkin, M. E., Derwent, R. G., and Pilling, M. J.: Protocol for the development of the Master Chemical Mechanism, MCM v3 (Part A): tropospheric degradation of nonaromatic volatile organic compounds, Atmos. Chem. Phys., 3, 161-180, doi:10.5194/acp-3-161-2003, 2003.

Slusher, D. L., Huey, L. G., Tanner, D. J., Flocke, F. M., and Roberts, J. M.: A thermal dissociation chemical ionization mass spectrometry (TD-CIMS) technique for the simultaneous measurement of peroxyacyl nitrates and dinitrogen pentoxide, J. Geophys. Res., 109, D19315, doi:10.1029/2004jd004670, 2004.
So, S., da Silva, G., and Wille, U.: The Atmospheric Chemistry of Enols: A Theoretical Study of the Vinyl Alcohol $+\mathrm{OH}+$ $\mathrm{O}_{2}$ Reaction Mechanism, Environ. Sci. Technol., 48, 6694-6701, doi:10.1021/es500319q, 2014.

Sommariva, R., de Gouw, J. A., Trainer, M., Atlas, E., Goldan, P. D., Kuster, W. C., Warneke, C., and Fehsenfeld, F. C.: Emissions and photochemistry of oxygenated VOCs in urban plumes in the Northeastern United States, Atmos. Chem. Phys., 11, 70817096, doi:10.5194/acp-11-7081-2011, 2011.

Stavrakou, T., Muller, J. F., Peeters, J., Razavi, A., Clarisse, L., Clerbaux, C., Coheur, P. F., Hurtmans, D., De Maziere, M., Vigouroux, C., Deutscher, N. M., Griffith, D. W. T., Jones, N., and Paton-Walsh, C.: Satellite evidence for a large source of formic acid from boreal and tropical forests, Nature Geosci., 5, 26-30, 2012.

Talbot, R. W., Beecher, K. M., Harriss, R. C., and Cofer III, W. R.: Atmospheric Geochemistry of Formic and Acetic Acids at a Mid-Latitude Temperate Site, J. Geophys. Res., 93, 1638-1652, doi:10.1029/JD093iD02p01638, 1988.

Tan, Y., Carlton, A. G., Seitzinger, S. P., and Turpin, B. J.: SOA from methylglyoxal in clouds and wet aerosols: Measurement and prediction of key products, Atmos. Environ., 44, 5218-5226, doi:10.1016/j.atmosenv.2010.08.045, 2010.

Thomas, E. R., Frost, G. J., and Rudich, Y.: Reactive uptake of ozone by proxies for organic aerosols: Surface-bound and gas-phase products, J. Geophys. Res.-Atmos., 106, 3045-3056, doi:10.1029/2000jd900595, 2001.

Veres, P., Roberts, J. M., Warneke, C., Welsh-Bon, D., Zahniser, M., Herndon, S., Fall, R., and de Gouw, J.: Development of negative-ion proton-transfer chemical-ionization mass spectrometry (NI-PT-CIMS) for the measurement of gas-phase organic acids in the atmosphere, Int. J. Mass Spectrom., 274, 48-55, doi:10.1016/j.ijms.2008.04.032, 2008.

Veres, P., Gilman, J. B., Roberts, J. M., Kuster, W. C., Warneke, C., Burling, I. R., and de Gouw, J.: Development and validation of a portable gas phase standard generation and calibration system for volatile organic compounds, Atmos. Meas. Tech., 3, 683-691, doi:10.5194/amt-3-683-2010, 2010.

Veres, P. R., Roberts, J. M., Cochran, A. K., Gilman, J. B., Kuster, W. C., Holloway, J. S., Graus, M., Flynn, J., Lefer, B., Warneke, C., and de Gouw, J.: Evidence of rapid production of organic acids in an urban air mass, Geophys. Res. Lett., 38, L17807, doi:10.1029/2011g1048420, 2011.

Vet, R., Artz, R. S., Carou, S., Shaw, M., Ro, C.-U., Aas, W., Baker, A., Bowersox, V. C., Dentener, F., Galy-Lacaux, C., Hou, A., Pienaar, J. J., Gillett, R., Forti, M. C., Gromov, S., Hara, H., Khodzher, T., Mahowald, N. M., Nickovic, S., Rao, P. S. P., and Reid, N. W.: A global assessment of precipitation chemistry and deposition of sulfur, nitrogen, sea salt, base cations, organic acids, acidity and $\mathrm{pH}$, and phosphorus, Atmos. Environ., 93, 3100, doi:10.1016/j.atmosenv.2013.10.060, 2014.

Vlasenko, A., George, I. J., and Abbatt, J. P. D.: Formation of Volatile Organic Compounds in the Heterogeneous Oxidation of Condensed-Phase Organic Films by Gas-Phase OH, J. Phys. Chem. A, 112, 1552-1560, doi:10.1021/jp0772979, 2008.

Warneke, C., de Gouw, J. A., Lovejoy, E. R., Murphy, P. C., Kuster, W. C., and Fall, R.: Development of proton-transfer ion trap-mass spectrometry: On-line detection and identification of volatile or- 
ganic compounds in air, J. Am. Soc. Mass Spectrom., 16, 13161324, doi:10.1016/j.jasms.2005.03.025, 2005.

Warneke, C., Veres, P., Holloway, J. S., Stutz, J., Tsai, C., Alvarez, S., Rappenglueck, B., Fehsenfeld, F. C., Graus, M., Gilman, J. B., and de Gouw, J. A.: Airborne formaldehyde measurements using PTR-MS: calibration, humidity dependence, intercomparison and initial results, Atmos. Meas. Tech., 4, 23452358, doi:10.5194/amt-4-2345-2011, 2011.

Warneke, C., Geiger, F., Edwards, P. M., Dube, W., Pétron, G., Kofler, J., Zahn, A., Brown, S. S., Graus, M., Gilman, J. B., Lerner, B. M., Peischl, J., Ryerson, T. B., de Gouw, J. A., and Roberts, J. M.: Volatile organic compound emissions from the oil and natural gas industry in the Uintah Basin, Utah: oil and gas well pad emissions compared to ambient air composition, Atmos. Chem. Phys., 14, 10977-10988, doi:10.5194/acp14-10977-2014, 2014

Welz, O., Eskola, A. J., Sheps, L., Rotavera, B., Savee, J. D., Scheer, A. M., Osborn, D. L., Lowe, D., Murray Booth, A., Xiao, P., Anwar H. Khan, M., Percival, C. J., Shallcross, D. E., and Taatjes, C. A.: Rate Coefficients of $\mathrm{C} 1$ and $\mathrm{C} 2$ Criegee Intermediate Reactions with Formic and Acetic Acid Near the Collision Limit: Direct Kinetics Measurements and Atmospheric Implications, Ange. Chem. Int. Edit., 126, 4635-4638, doi:10.1002/ange.201400964, 2014

Wesely, M. L.: Parameterization of surface resistances to gaseous dry deposition in regional-scale numerical models, Atmos. Environ., 23, 1293-1304, doi:10.1016/0004-6981(89)90153-4, 1989.

Wild, R. J., Edwards, P. M., Dube, W. P., Baumann, K., Edgerton, E. S., Quinn, P. K., Roberts, J. M., Rollins, A. W., Veres, P. R., Warneke, C., Williams, E. J., Yuan, B., and Brown, S. S.: A Measurement of Total Reactive Nitrogen, $\mathrm{NO}_{\mathrm{y}}$, together with $\mathrm{NO}_{2}$, $\mathrm{NO}$, and $\mathrm{O}_{3}$ via Cavity Ring-down Spectroscopy, Environ. Sci. Technol., 48, 9609-9615, doi:10.1021/es501896w, 2014.
Wyche, K. P., Monks, P. S., Ellis, A. M., Cordell, R. L., Parker, A E., Whyte, C., Metzger, A., Dommen, J., Duplissy, J., Prevot, A. S. H., Baltensperger, U., Rickard, A. R., and Wulfert, F.: Gas phase precursors to anthropogenic secondary organic aerosol: detailed observations of 1,3,5-trimethylbenzene photooxidation, Atmos. Chem. Phys., 9, 635-665, doi:10.5194/acp-9-635-2009, 2009.

Yatavelli, R. L. N., Stark, H., Thompson, S. L., Kimmel, J. R., Cubison, M. J., Day, D. A., Campuzano-Jost, P., Palm, B. B., Hodzic, A., Thornton, J. A., Jayne, J. T., Worsnop, D. R., and Jimenez, J. L.: Semicontinuous measurements of gas-particle partitioning of organic acids in a ponderosa pine forest using a MOVI-HRToFCIMS, Atmos. Chem. Phys., 14, 1527-1546, doi:10.5194/acp14-1527-2014, 2014

Zhang, R., Suh, I., Zhao, J., Zhang, D., Fortner, E. C., Tie, X., Molina, L. T., and Molina, M. J.: Atmospheric New Particle Formation Enhanced by Organic Acids, Science, 304, 1487-1490, 10.1126/science.1095139, 2004.

Zhang, X., Liu, J., Parker, E. T., Hayes, P. L., Jimenez, J. L., de Gouw, J. A., Flynn, J. H., Grossberg, N., Lefer, B. L., and Weber, R. J.: On the gas-particle partitioning of soluble organic aerosol in two urban atmospheres with contrasting emissions: 1. Bulk water-soluble organic carbon, J. Geophys. Res., 117, D00V16, doi:10.1029/2012jd017908, 2012.

Zhang, X., Schwantes, R. H., Coggon, M. M., Loza, C. L., Schilling, K. A., Flagan, R. C., and Seinfeld, J. H.: Role of ozone in SOA formation from alkane photooxidation, Atmos. Chem. Phys., 14, 1733-1753, doi:10.5194/acp-14-1733-2014, 2014. 